\title{
Lithostratigraphy and Inorganic Geochemical Studies of Cretaceous-Tertiary Lithofacies from Nigerian Three Inland Basin
}

\author{
Olugbenga A. Boboye' ${ }^{1}$, Mayowa S. Adeyemi ${ }^{1}$, Henry. Y. Madukwe ${ }^{2}$ \\ ${ }^{1}$ Department of Geology, University of Ibadan, Ibadan, Nigeria \\ ${ }^{2}$ Department of Geology, Ekiti State University, Ado Ekiti, Nigeria \\ Email: boboyegbenga@yahoo.com,oa.boboye@mail.ui.edu.ng, henrymadukwe@yahoo.co.uk
}

How to cite this paper: Boboye, O.A., Adeyemi, M.S. and Madukwe, H.Y. (2018) Lithostratigraphy and Inorganic Geochemical Studies of Cretaceous-Tertiary Lithofacies from Nigerian Three Inland Basin. Open Journal of Geology, 8, 711-736. https://doi.org/10.4236/ojg.2018.87042

Received: May 17, 2018

Accepted: July 27, 2018

Published: July 30, 2018

Copyright $\odot 2018$ by authors and Scientific Research Publishing Inc. This work is licensed under the Creative Commons Attribution International License (CC BY 4.0).

http://creativecommons.org/licenses/by/4.0/

\begin{abstract}
Studies from selected samples from Chad (Kanadi-1, Albarka-1 and Tuma-1), Sokoto (Dange-1) and Dahomey Basins (Seme-1), were subjected to detailed lithostratigraphic description and inorganic geochemical studies with the aim of determining the provenance, tectonic setting, depositional environment and geochemical characterization. This involves detailed lithologic description, Inductively Coupled Plasma Emission Spectrometry (ICP-ES) and Inductively Coupled Plasma Mass Spectrometry (ICP-MS) through lithium metaborate fusion method. The lithologies of the study wells from Chad, Sokoto and Dahomey Basins comprise of mudstone, dark shale, brownish sandstone and light brownish shale; mudstone and dark brownish shale and clay, dark brownish shale, siltstone respectively. The geochemical result showed an abundance of $\mathrm{SiO}_{2}$ with an average of $75.05 \%, \mathrm{Al}_{2} \mathrm{O}_{3}$ average of $12.51 \%$ (sandstone), values of $18.10 \%$ to $10.12 \%$ and $5.51 \%$ to $16.17 \%$ (shale). The abundance of $\mathrm{Fe}_{2} \mathrm{O}_{3}$ range from $2.12 \%$ to $8.56 \%$ while the other major elements have very low concentration. The high $\mathrm{SiO}_{2}$ content indicated a quartz rich adjoining source rock while low values of ratio $\mathrm{K}_{2} \mathrm{O} / \mathrm{Al}_{2} \mathrm{O}_{3}$ and $\mathrm{Na}_{2} \mathrm{O} / \mathrm{Al}_{2} \mathrm{O}_{3}$, coupled with high average values $(<70 \%)$ of Plagioclase Index of Alteration (PIA), Chemical Index of Alteration (CIA) and Chemical Index of Weathering (CIW) indicated intense weathering condition and humid climate at the source area. The sediments classification includes greywacke, arkose, litharenite and quartz arenite. A-K-F plot indicated transitional marine environment. Discrimination function plots revealed felsic igneous, quartzose sedimentary and intermediate igneous provenances. The plot of La-Th-Sc showed deposits of passive margin setting. Chondrite normalized REE plot showed an enrichment of light REE with strong negative Eu anomaly which is an indication of a felsic source. Conclusively, study areas consist of marine deposits
\end{abstract}


with plutonic igneous rock as the main source rock couple with low grade metamorphic and quartzose recycled rocks deposited in transitional marine environment under intense weathering in a tropical, humid climatic condition.

\section{Keywords}

Provenance, Inductively Coupled Plasma Emission Spectrometry, Inductively Coupled Plasma Mass Spectrometry, Environment

\section{Introduction}

The geochemistry of clastic sediment has been shown to reflect past environment of deposition, weathering condition, provenance, tectonic settings and climatic condition that prevailed during their deposition. As sediment is known to play prominent roles in interpreting their history and source history of deposition, paleogeography and tectonic reconstruction, the Precambrian domain of West Africa accommodates vital depositional basins, amongst which are the Dahomey Embayment, Sokoto and Chad Basins. Dahomey Embayment is a coastal sedimentary basin which covers much of the continental margin of the Gulf of Guinea. It extends from Volta delta in Ghana to the west of Okitipupa ridge in Nigeria. The eastern half of the basin lies within Nigeria and contains Cretaceous to Recent sediments. The geology, stratigraphy, sedimentology, organic and inorganic geochemical studies of different parts of the basin have been studied by many workers [1] [2] [3] [4]. The basin has proven to be of great geological importance, particularly because of the extensive occurrences of limestone, glass sand, phosphate and bitumen [4].

The Sokoto Basin in northwestern part of Nigeria consists predominantly of a gently undulating plain with an average elevation varying from $250 \mathrm{~m}$ to 400 $\mathrm{m}$ above sea level. The sediment of the basin was accumulated during four main phase of depositions. Overlying the Precambrian basement uniformably, the Illo and Gundumi formations, made up of grits and clays, constitute the Pre-Maastrichtian-Continental Intercalaire of West Africa. They are overlaid unconformably by the Maastrichtian Rima group, consisting of mudstone and friable sandstone separated by the fossiliferous, shally Dukumuje Formation. The Dange and Gamba formations, mainly shale, separated by the calcareous Kalambaina Formation constitute the Palaeocene Sokoto group. The overlying continental Gwandu Formation forms the Post Palaeocene Continental Terminal. These sediments dip gently and thicken gradually towards the northwest, with a maximum thickness of over $1200 \mathrm{~m}$ near the frontier with the Niger republic. Major and trace element geochemistry has being found to reflect the tectonic setting of the basin [5], particularly the insoluble and immobile elements. The Chad Basin extends into parts of Niger, Chad, Central African Republic, and Cameroon [6]. The Chad Basin lies within a vast area of Central and West 
Africa at an elevation of between $200 \mathrm{~m}$ and $500 \mathrm{~m}$ above sea level and covering approximately $230,000 \mathrm{~km}^{2}$. The basin has been referred to as an interior sag ba$\sin$ [7], due to a sagging episode that has affected it before the onset of continental separation during which a rift system junction was formed providing appropriate site for sedimentation. It, therefore, lies at the junction of basins (comprising the West African rift) which becomes active in the early Cretaceous when Gondwana started to split up into component plates [8]. Sediments are mainly continental, sparsely fossiliferous, poorly sorted, and medium to coarse-grained, feldspathic sandstones called the Bima Sandstone. A transitional calcareous deposit-Gongila Formation that accompanied the onset of marine incursions into the basin-overlies the Bima Sandstones. These are overlain unconformably by graptolitic Keri-Keri shales while the Chad Formation overlies it to the Earth's surface [9]. Major, trace and rare earth elements are of great importance in provenance and tectonic studies because of their variable signatures during sedimentary processes.

This study therefore evaluates the geochemical characteristics of Chad, Dahomey and Sokoto Basins, using their lithofacies and geochemistry to characterize their provenance, depositional environments and with a view to provide a better insight into the palaeoenvironmental, palaeo-weathering and palaeogeographical conditions that prevailed during their emplacement. This study also appraises the relationship between various sedimentary processes and the inorganic geochemical signatures of the basins.

\section{Location of the Study Area}

The eastern Dahomey Embayment is located at the Seme border area of Lagos between longitude $2^{\circ} 42^{\prime} 57.766^{\prime \prime} \mathrm{N}$ and longitude $2^{\circ} 40^{\prime} 43.804^{\prime \prime} \mathrm{N}$ and latitude $6^{\circ} 11^{\prime} 46.704^{\prime \prime E}$ to latitude $6^{\circ} 14^{\prime} 59.805^{\prime \prime}$. Dange-1 is located between latitude $10^{\circ}$ and $14^{\circ} \mathrm{N}$ and longitude $3^{\circ}$ and $7^{\circ} \mathrm{E}$ within the Sokoto Basin. Three wells were studied in the Chad Basin, each within the depth of $2000 \mathrm{~m}$ (Albarka-1, Tuma-1 and Kanadi-1 wells) between latitude $13^{\circ} 8^{\prime} 28^{\prime \prime} \mathrm{N}$ and latitude $14^{\circ} 13^{\prime} \mathrm{N}$ and longitude $13^{\circ} \mathrm{E}$ to $14^{\circ} \mathrm{E}$. All the study areas are accessible by major feeder roads and footpaths (Figure 1).

\section{Previous Works}

The geochemical composition of terrigenous sedimentary rock is a function of the complex interplay of various variables [5]. Recent investigations on geochemical characteristics of ancient and modern detritus have been carried out to infer the weathering, provenance and tectonic setting [5] [10] [11] [12]. Allen gave a generalized view on the sedimentary characteristic of depositional environment of reservoirs and reviewed the sedimentological processes responsible for the deltaic deposits [13]. Bhatia worked on plate tectonic and geochemical composition of sandstone and using elements of geochemistry to reflect the distinct sedimentary provenance and tectonic setting of each suite [5]. Bhatia and Crook reported the trace element characteristic of greywackes and tectonic 


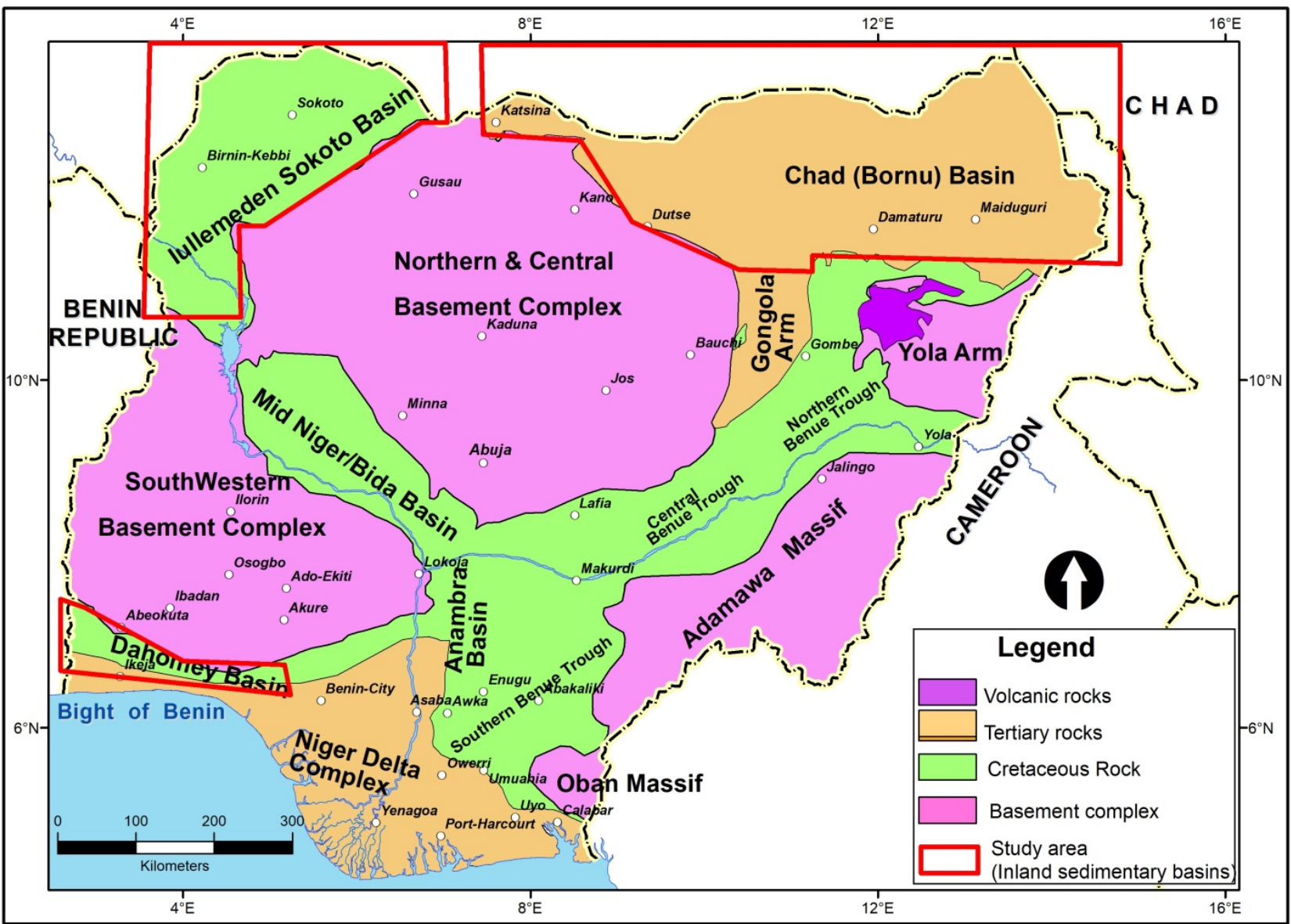

Figure 1. Geological map of Nigeria showing the three inland sedimentary basins.

settings discrimination of sedimentary basins [10]. Berner using inorganic geochemical analysis deduced that lithologies of the sandstone complex in the Brazos Riverbird section of Texas are mixture of diverse proportion of clastic compounds of high energy environment and thus strongly supported that the deposits are reworked [14].

In Nigeria, less attention has been given to Chad Basin, partly due to the low petroleum potential rating assigned to the basin and due to the lack of outcrop. The origin of the Chad Basin as a sub-unit of the large and connected chain of the interior cratonic basin in Africa, whose origin is closely related to the structural evolution of Africa and especially the separation of the Africa and South America continents in the Cretaceous has attracted the attention of many workers [9] [15]-[20]. These workers believe that the basin is a product of rifting, subsidence and sedimentation that accompanies the separation of the Africa and the South America continents. Pioneering works on the geology and hydrogeology of Chad Basin in Nigeria includes Barber who focused on the availability of pressured (artisan) water and the hydrogeology of Maiduguri and Bornu province [21]. Petters did the regional correlation of sediments in the Western African Cratonic basins (Chad, Sokoto and Taoudeni), covering stratigraphic unit of basins in Nigeria, Chad, Niger Republics and Mali [22]. Work on the 
Cretaceous sediments presented further evidence for the existence of marine Cenomanian, Lower Turonian and Maastrichtian in the Upper Benue Trough of Nigeria where lateral equivalents of the Gongila and the Fika Shale Formations of the Chad Basin were reported [18] [23]. However, since the Upper Benue trough and the southern Chad basin Formation are correlatable, geologic inferences on the Upper Benue trough have over the years been extrapolated into the Chad basin [24].

The geology of Sokoto Basin has been studied by various workers; the bulk of the investigation has been confined to the general geology including the stratigraphy relationships of the formation, biostratigraphy and possible enrichment of radioactive minerals in the sediment. Falcons worked on the Geology and Geography of northern Nigeria and postulate a region upheaval resulting in the folding and fracturing of the Cretaceous rock and date it as Eocene [25]. Raebrun and Tattam carried out lithologic as well as palaeontological study of the Sokoto area and divide the stratigraphy into clay shale and calcareous group [26]. An Eocene age was assigned to the clay shale (with limestone band) which underlies the calcareous group. The mappings of the geology of a large segment of the Sokoto Basin and numerous vertebrate fossils have been described [27].

The earliest studies of the Dahomey Basin started from Togo, where the outcrop belonging to the basin was studied in Mono valley [28]. Abeokuta group is the oldest formation in the basin, lying non-conformably on the basement [1]. Omatsola and Adegoke reported the lithostratigraphy of Dahomey Basin and recognized three formations belonging to the Abeokuta group based on lithologic homogeneity and similarity of origin [3]. Boboye and Omotosho reported the petrology and geochemical appraisal of the Ibese lithofacies and concluded that three different microfacies recognized are shelly biomicrite, shelly biosparmicrite and alga biosparmicrite and that the predominance of micrite as the cementing matrix revealed that the rock was deposited in a quiet shallow inner shelf environment occasioned by storm waves [29]. The stratigraphy of the sediment in the Nigeria sector of the basin is controversial due to diverse stratigraphy names assigned to the same formation in different localities of the ba$\sin$.

\section{Materials and Method}

The analyses carried out on the samples were inorganic geochemical analysis using inductively coupled plasma electron spectrometry (ICP-ES) and inductively coupled plasma mass spectrometry (ICP-MS) through Lithium Metaborate fusion method. Chemical analysis of seventeen (17) representative samples of sandstone and shale were performed at SGS Laboratory, South Africa, for determination of major, trace and rare earth elements.

The samples were dried at room temperature, pulverized and sieved to -80 mesh; crushed to $80 \%$ passing $2 \mathrm{~mm}, 500 \mathrm{~g}$ split by riffle splitter and the $500 \mathrm{~g}$ split of $2 \mathrm{~mm}$ material pulverized to $85 \%$ passing $75 \mu \mathrm{m}$ in a Carbon steel ring and puck pulverized prior to the determination of multi elements by sodium 
peroxide fusion ICP-OES + ICP-MS. Calibration standards and reagent blanks were added to the sample sequences to avoid contamination, all samples were washed thoroughly using deionized water prior to preparation for the ICP analysis.

Samples solutions were analyzed by ICP-MS and ICP-ES with data being acquired for ten (10) major elements $\left(\mathrm{SiO}_{2}, \mathrm{Al}_{2} \mathrm{O}_{3}, \mathrm{TiO}_{2}, \mathrm{Fe}_{2} \mathrm{O}_{3}, \mathrm{MgO}, \mathrm{CaO}, \mathrm{Na}_{2} \mathrm{O}\right.$, $\mathrm{K}_{2} \mathrm{O}$, and $\mathrm{P}_{2} \mathrm{O}_{5}$ ), seventeen (17) trace elements ( $\mathrm{Ba}, \mathrm{Co}, \mathrm{Cr}, \mathrm{Cs}, \mathrm{Cu}, \mathrm{Li}, \mathrm{Ga}, \mathrm{Hf}$, $\mathrm{Nb}, \mathrm{Rb}, \mathrm{Sc}, \mathrm{Sr}, \mathrm{Ta}, \mathrm{U}, \mathrm{V}, \mathrm{Y}$, and $\mathrm{Zr}$ ) and fourteen (14) rare earth elements (La, $\mathrm{Ce}, \mathrm{Pr}, \mathrm{Nd}, \mathrm{Sm}, \mathrm{Eu}, \mathrm{Gd}, \mathrm{Tb}, \mathrm{Dy}, \mathrm{Ho}, \mathrm{Er}, \mathrm{Tm}, \mathrm{Yb}$, and $\mathrm{Lu}$ ). The data were subjected to statistical treatment; both univariate and multivariate statistical analysis were done using SPSS (One way Anova, Descriptive table and multiple comparisons table) and Microsoft excels to determine elemental interrelationship. Index elements were used to classify others into biogenic, terrigenous and authigenic, all based on the source types.

\section{Results and Discussion}

\subsection{Lithostratigraphic Description}

The lithostratigraphy has described and organized changes on lithology into distinctive units. The lithology sections are described based on their texture, depth and colour (Figures 2-6).

\subsection{Inorganic Geochemistry}

\subsubsection{Major Elements Geochemistry}

This is a function of the complex inter play of various variables such as provenance, weathering, transportation and diagenesis. It is relatively difficult to establish the relationship between the mineralogy of sedimentary rock and their chemical composition, unlike as it is in many igneous rocks. The geochemical classification of sedimentary sediment does not follow the conventional mineralogy of the quartz-feldspar-lithic fragment classification but it tends to differentiate between mature and immature sediments, however it can be partly used to determine the degree of alteration of the source materials, it can also be of use when contemplating certain trends in the general composition of the sedimentary rocks and to decipher the weathering profile of the rock [30] [31] [32] [33]. The abundance of the major elements analyzed (Table 1) from the study areas shows variation of element composition of all the samples, indicting the heterogeneity of the sediment suite and difference in provenance and sedimentary environment of the sediment. Variations in the chemical deposition reflect changes in the mineralogical composition of the sediments.

$\mathrm{SiO}_{2}$ abundance ranges from $59.52 \%$ to $83.88 \%$ with an average of $75.05 \%$. This average value is higher than the value for upper Continental crust. This high abundance of $\mathrm{SiO}_{2}$ from the study areas indicate the dominance of quartz grains in the clastic sediment with little contribution from other detrital source which is also an indication of acidic plutonic igneous rock. The average content of 


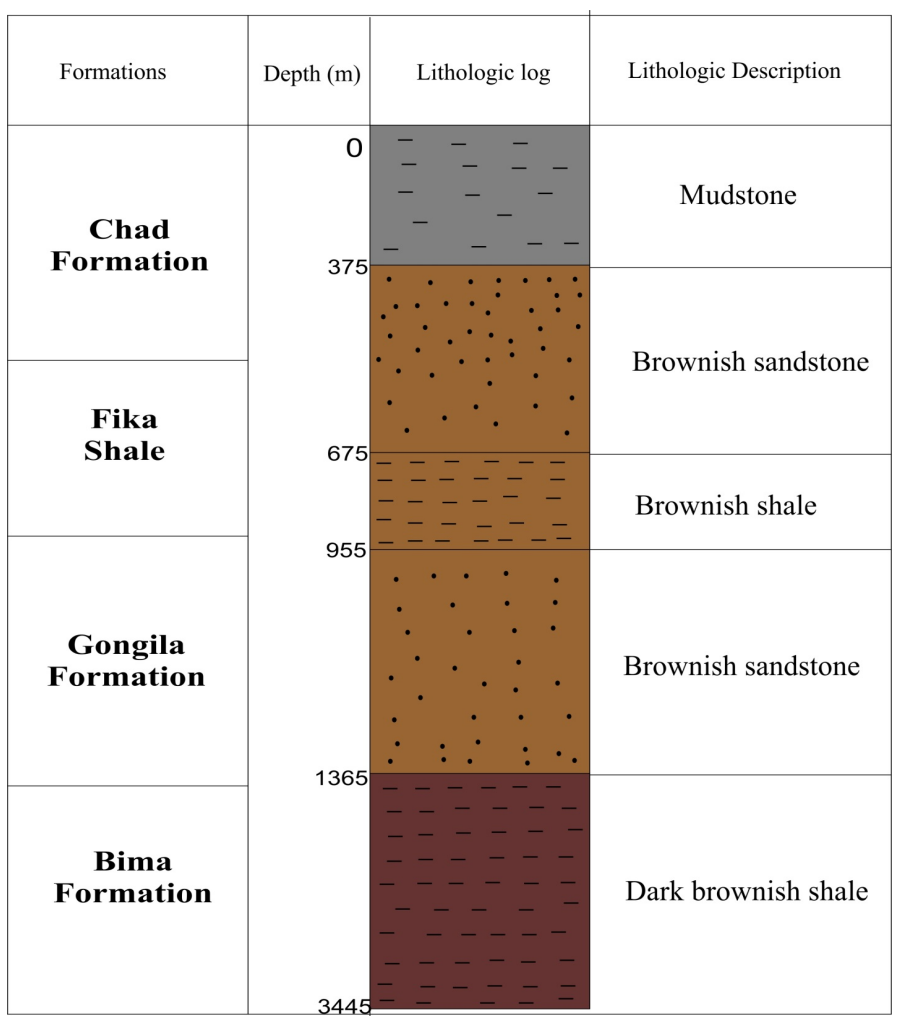

Figure 2. Cross section of the stratigraphy of Albarka-1 well from Chad Basin.

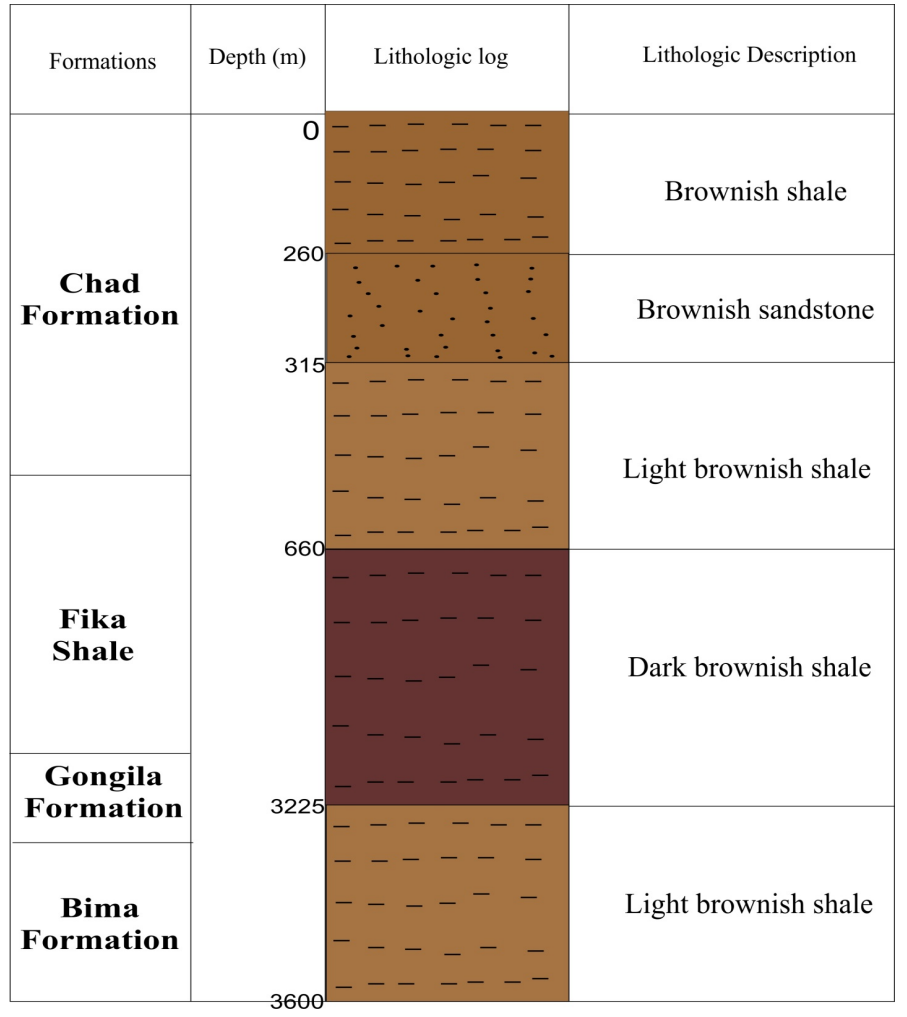

Figure 3. Cross section of the stratigraphy of Tuma-1 well from Chad Basin. 


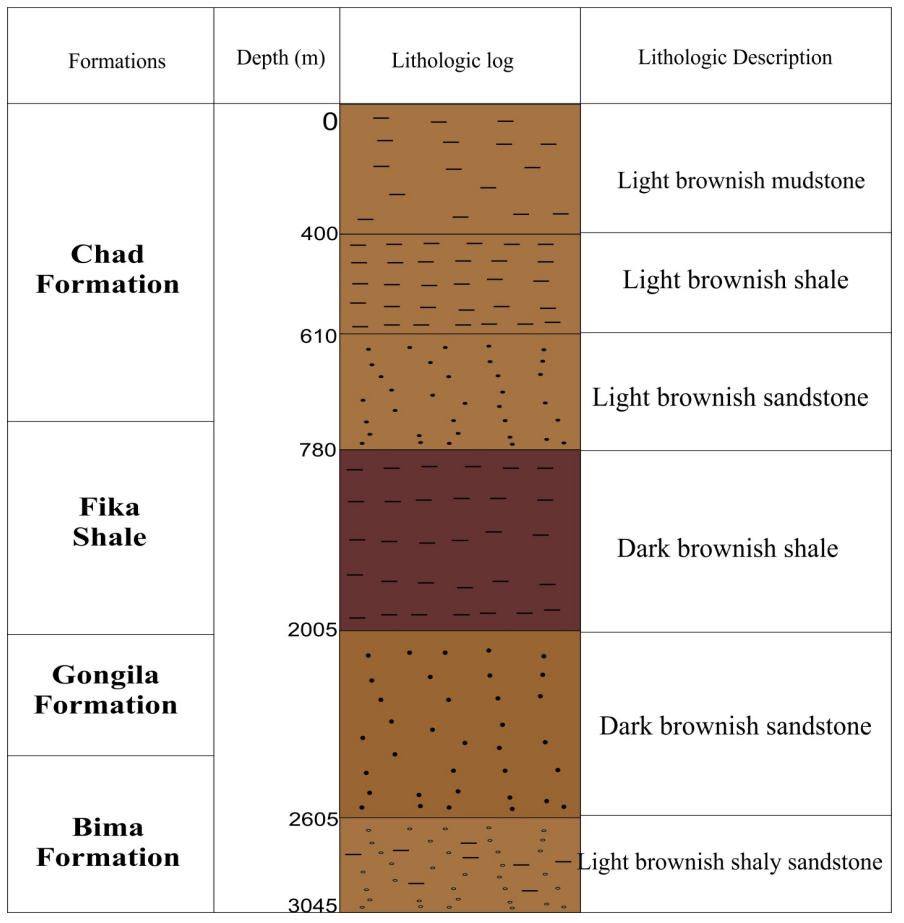

Figure 4. Cross section of the stratigraphy of Kanadi-1 well from Chad Basin.

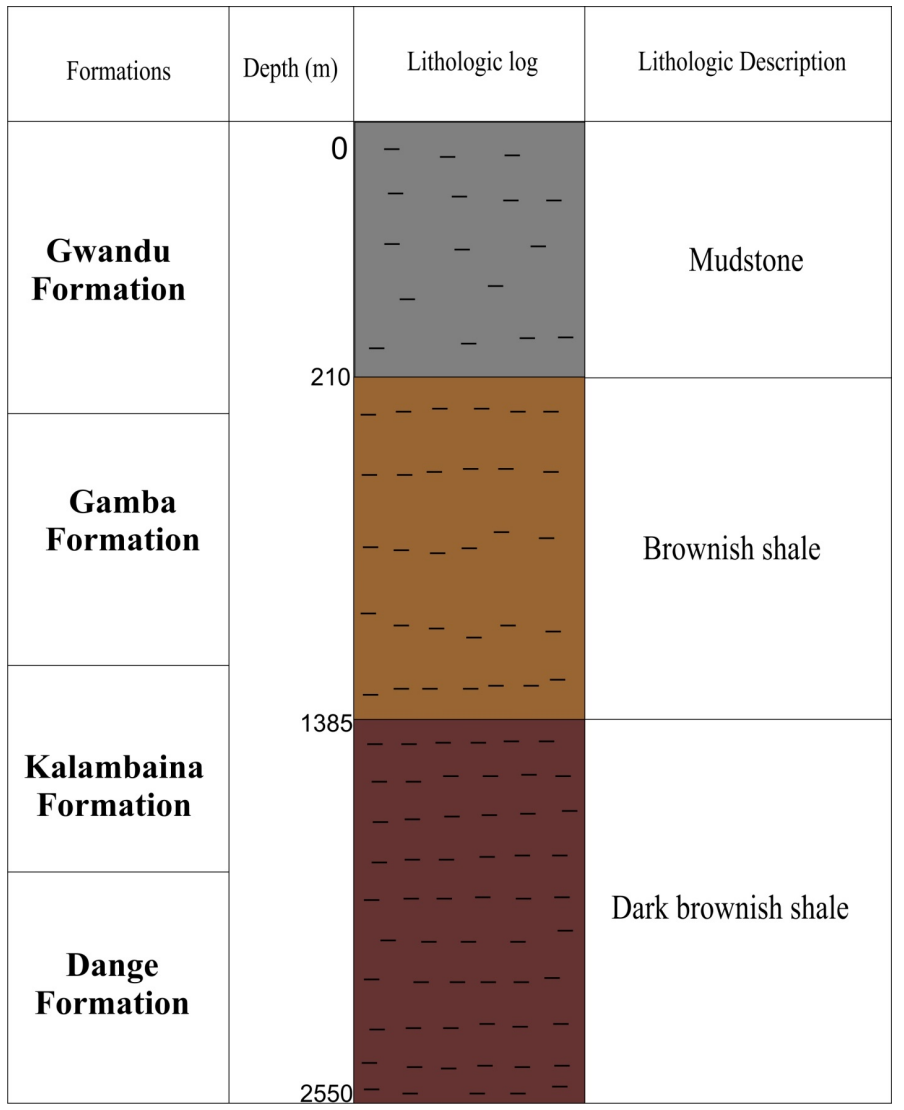

Figure 5. Cross section of the stratigraphy of Dange-1 well from Sokoto Basin. 


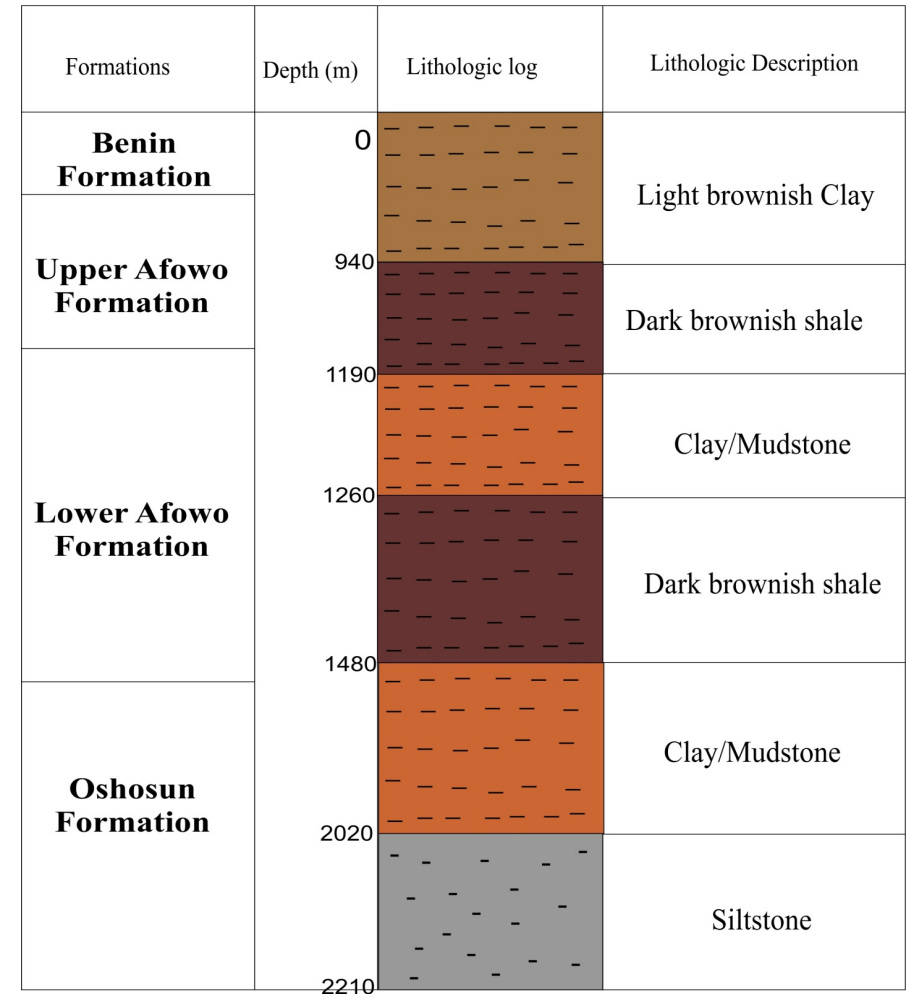

Figure 6. Cross section of the stratigraphy of Seme-1 well from Dahomey Basin.

Table 1. Major elemental compositions.

\begin{tabular}{ccccccccccc}
\hline $\begin{array}{c}\text { Sample } \\
\text { No }\end{array}$ & $\begin{array}{c}\mathrm{SiO}_{2} \\
(\%)\end{array}$ & $\begin{array}{c}\mathrm{Al}_{2} \mathrm{O}_{3} \\
(\%)\end{array}$ & $\begin{array}{c}\mathrm{Fe}_{2} \mathrm{O}_{3} \\
(\%)\end{array}$ & $\begin{array}{c}\mathrm{MgO} \\
(\%)\end{array}$ & $\begin{array}{c}\mathrm{CaO} \\
(\%)\end{array}$ & $\begin{array}{c}\mathrm{Na}_{2} \mathrm{O} \\
(\%)\end{array}$ & $\begin{array}{c}\mathrm{K}_{2} \mathrm{O} \\
(\%)\end{array}$ & $\begin{array}{c}\mathrm{TiO}_{2} \\
(\%)\end{array}$ & $\begin{array}{c}\mathrm{MnO} \\
(\%)\end{array}$ & $\begin{array}{c}\mathrm{P}_{2} \mathrm{O}_{5} \\
(\%)\end{array}$ \\
\hline $\mathrm{Kd}-\mathrm{A}$ & 83.88 & 11.26 & 2.69 & 0.83 & 0.53 & 0.01 & 0.60 & 0.70 & 0.04 & 0.12 \\
$\mathrm{Kd}-\mathrm{B}$ & 69.02 & 15.99 & 6.56 & 3.74 & 3.39 & 0.01 & 0.15 & 0.84 & 0.05 & 0.23 \\
$\mathrm{Kd}-\mathrm{C}$ & 73.51 & 18.10 & 5.12 & 0.38 & 1.04 & 0.01 & 0.71 & 0.92 & 0.03 & 0.16 \\
$\mathrm{Kd}-\mathrm{D}$ & 59.52 & 11.68 & 8.26 & 6.24 & 5.68 & 0.01 & 6.66 & 0.70 & 0.13 & 1.10 \\
$\mathrm{Kd}-\mathrm{E}$ & 58.01 & 11.96 & 8.56 & 6.60 & 6.28 & 0.01 & 6.48 & 0.72 & 0.13 & 1.21 \\
$\mathrm{Kd}-\mathrm{F}$ & 81.23 & 10.13 & 3.79 & 0.71 & 1.71 & 0.01 & 1.75 & 0.43 & 0.08 & 0.14 \\
$\mathrm{Ak}-\mathrm{A}$ & 67.19 & 16.17 & 6.85 & 3.88 & 3.58 & 0.01 & 1.10 & 0.81 & 0.05 & 0.32 \\
$\mathrm{Ak}-\mathrm{B}$ & 82.61 & 11.22 & 3.47 & 0.73 & 0.55 & 0.01 & 0.60 & 0.63 & 0.03 & 0.12 \\
Ak-C & 83.81 & 10.71 & 3.13 & 0.56 & 0.49 & 0.01 & 0.54 & 0.55 & 0.03 & 0.12 \\
$\mathrm{Ak}-\mathrm{D}$ & 81.60 & 12.06 & 3.79 & 0.28 & 0.70 & 0.01 & 0.69 & 0.68 & 0.03 & 0.14 \\
Ak-E & 59.26 & 12.55 & 8.17 & 6.08 & 5.53 & 0.01 & 6.59 & 0.65 & 0.13 & 1.01 \\
Tm-A & 74.58 & 17.91 & 4.72 & 0.35 & 0.83 & 0.01 & 0.63 & 0.78 & 0.03 & 0.14 \\
Tm-B & 83.03 & 11.56 & 3.03 & 0.66 & 0.42 & 0.01 & 0.59 & 0.57 & 0.03 & 0.07 \\
Tm-C & 86.16 & 8.20 & 2.11 & 0.43 & 0.85 & 0.01 & 1.87 & 0.20 & 0.04 & 0.09 \\
Tm-D & 62.40 & 12.87 & 6.79 & 5.07 & 4.69 & 0.01 & 6.49 & 0.65 & 0.10 & 0.89 \\
Dg-A & 81.47 & 7.79 & 2.92 & 0.15 & 2.92 & 0.01 & 0.37 & 0.53 & 0.22 & 0.92 \\
Sm-A & 8.67 & 5.52 & 2.67 & 0.42 & 2.67 & 0.01 & 2.25 & 0.17 & 0.05 & 0.14 \\
UCC & 65.0 & 5.0 & 15.2 & 2.2 & 4.2 & 3.9 & 0.6 & 3.4 & 0.08 & - \\
\hline
\end{tabular}

$\mathrm{Kd}=$ Kanadi -1 well; $\mathrm{Ak}=$ Albarka-1 well; $\mathrm{Tm}=$ Tuma-1 well; $\mathrm{Dg}=$ Dange well; $\mathrm{Sm}=$ Seme well; $\mathrm{UCC}=$ Upper Continental Crust (Taylor and McLennan [45]). 
$\mathrm{Al}_{2} \mathrm{O}_{3}$ for sandstone is moderately high ranging from $18.10 \%$ to $10.12 \%$ and also $5.51 \%$ to $16.17 \%$ for the shale. The concentration of Aluminum (Al) can be assigned to the association with fine grain aluminosilicate detrital fraction, the occurrence accounts for the high values of $\mathrm{Al}_{2} \mathrm{O}_{3}$ which is evident in sandstones within the study areas [34]. $\mathrm{Fe}_{2} \mathrm{O}_{3}$ values range from $2.12 \%-8.56 \%$ while the other major elements have very low concentration, which can be expected for sediment that is rich in $\mathrm{SiO}_{2}$.

The chemical composition of carbonate components of ancient limestone may serve as a potential tool for evaluating the degree of diagenesis and for detecting the original mineralogy of the different stabilized carbonate phases [35]. However, the geochemistry of limestone in Kalabiana and Ewekoro Formations from Sokoto and Dahomey Basins show that $\mathrm{CaO}$ concentrations range from $44.72 \%$ $55.49 \%($ mean $=50.18 \%), \mathrm{SiO}_{2}$ range from $0.26 \%-13.78 \%$ (mean $\left.=5.97 \%\right)$ and $\mathrm{Fe}_{2} \mathrm{O}_{3}$ range from $0.13 \%-1.64 \%$ (mean $=0.77 \%$ ), $\mathrm{MgO}$ and $\mathrm{Al}_{2} \mathrm{O}_{3}$ contents varying between $0.24 \%-0.80 \%$ and $0.05 \%-1.17 \%$ (mean $=0.65 \%$ and $0.49 \%$ ) respectively, this conform with the moderately high value of $\mathrm{CaO}$ (5.60\%) from Dange Formation (Sokoto Basin) within the same basin. This suggests that a correlation could be established for evaluating the degree of diagenesis within these formations. $\mathrm{K}_{2} \mathrm{O} / \mathrm{Al}_{2} \mathrm{O}_{3}$ ratio values in the sediments range between 0.0 to 0.3 and 0.3 to 0.9 respectively [36]. In the study areas, $\mathrm{K}_{2} \mathrm{O} / \mathrm{Al}_{2} \mathrm{O}_{3}$ ratio varies from 0.01 to 0.50 and generally falls within the range of clay mineral and feldspar. $\mathrm{TiO}_{2}$ increases slightly with $\mathrm{Al}_{2} \mathrm{O}_{3}$ for all the studied wells suggesting it is probably associated with phyllosilicate especially with illite, this is also in agreement with the strong positive correlation between $\mathrm{TiO}_{2}(\%)$ and $\mathrm{Al}_{2} \mathrm{O}_{3}(\%)$ for the study wells [37] (Figure 7). However the correlation values for $\mathrm{Fe}_{2} \mathrm{O}_{3}$, $\mathrm{Na}_{2} \mathrm{O}$, with $\mathrm{Al}_{2} \mathrm{O}_{3}$ are negative for all the wells suggesting their non-association with phyllosilicates which implies probably other source of input. The higher value of $\mathrm{K}_{2} \mathrm{O}$ with respect to $\mathrm{Na}_{2} \mathrm{O}$ (Table 1 ) emphasizes the fact that $\mathrm{K}$-feldspar is relatively more resistant to weathering than $\mathrm{Na}$-feldspar. Low values of the ratios of $\mathrm{Na}_{2} \mathrm{O} / \mathrm{Al}_{2} \mathrm{O}_{3}(0.0006-0.002), \mathrm{Na}_{2} \mathrm{O} / \mathrm{TiO}_{2}(0.0009-0.002)$ and $\mathrm{Na}_{2} \mathrm{O} / \mathrm{K}_{2} \mathrm{O}$ (0.009 - 0.03) (Table 2), indicate high chemical weathering. Compared with other major elements, concentration of $\mathrm{Fe}_{2} \mathrm{O}_{3}$ and $\mathrm{TiO}_{2}$ indicate the presence of iron-titanium minerals (hematite, anatase and rutiles). Marked negative correlation is shown by $\mathrm{SiO}_{2}$ with $\mathrm{Al}_{2} \mathrm{O}_{3}$ due to most of the silica being sequestered in quartz. The negative correlation of $\mathrm{SiO}_{2}$ with $\mathrm{Al}_{2} \mathrm{O}_{3}, \mathrm{~K}_{2} \mathrm{O}$ and $\mathrm{Na}_{2} \mathrm{O}$ suggest that the aluminosilicate and feldspar do not contribute much silica to the sediment [11]. The low values of the ratios $\mathrm{TiO}_{2} / \mathrm{Al}_{2} \mathrm{O}_{3}(0.02-0.07)$ and $\mathrm{Na}_{2} \mathrm{O} / \mathrm{K}_{2} \mathrm{O}(0.001-$ $0.07)$ for all the wells indicate that the sediments are chemically mature.

The correlation of $\mathrm{Al}_{2} \mathrm{O}_{3}$ with $\mathrm{MgO}, \mathrm{MnO}$ and $\mathrm{CaO}$ are negative and their values are insignificant (Figure 7 and Figure 8). The negative correlation between $\mathrm{K}_{2} \mathrm{O}$ and $\mathrm{Al}_{2} \mathrm{O}_{3}$ suggest that the concentration of the $\mathrm{K}$-bearing minerals does not have significant influence on the distribution of $\mathrm{Al}$ and suggests also that the abundance of these elements is not controlled by the content of clay minerals within the study areas [38]. A strong negative correlation of $\mathrm{SiO}_{2}$ and 

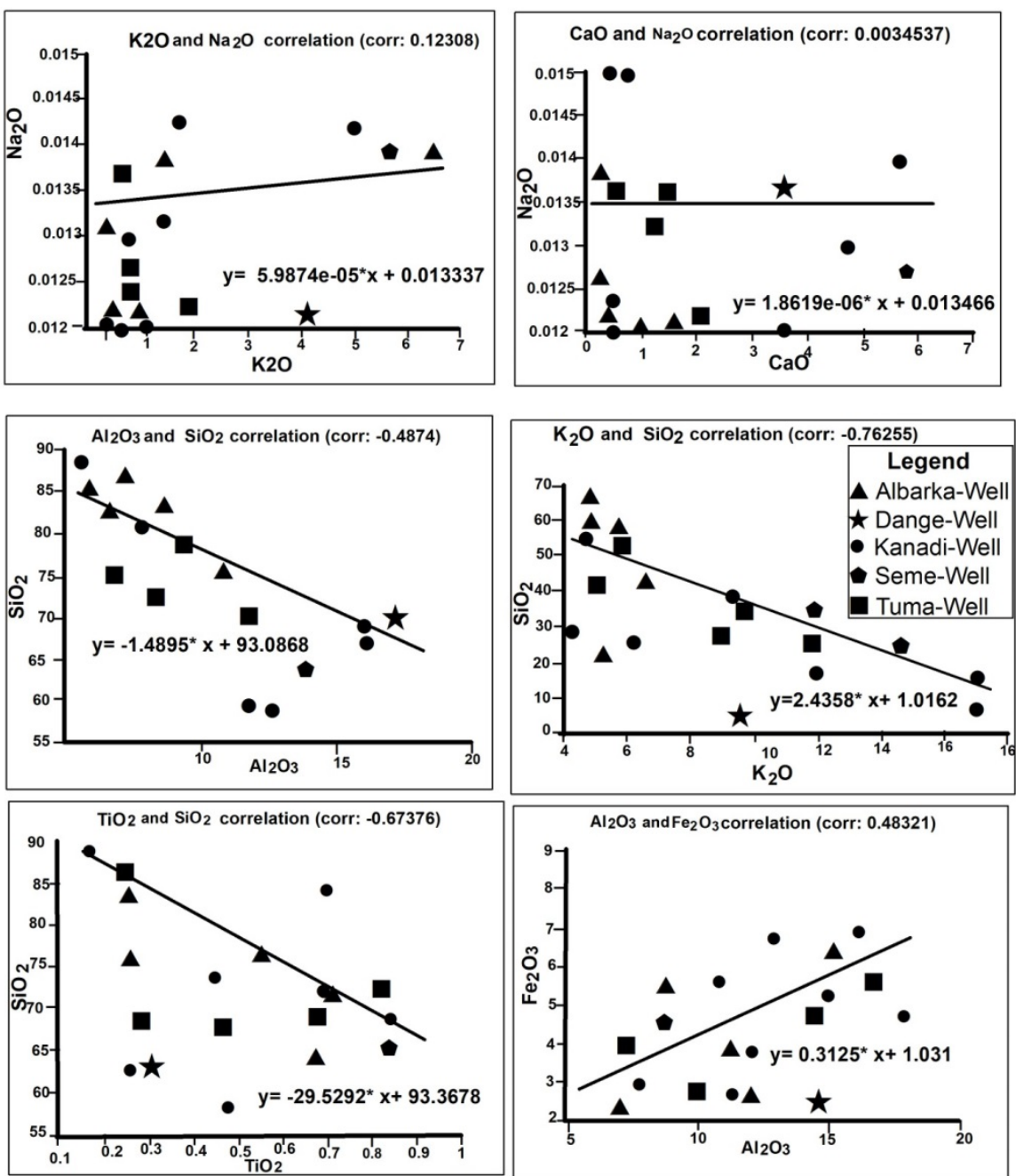

Figure 7. Bivariate correlation plots of major elements in the study wells.

$\mathrm{TiO}_{2}$ suggest that $\mathrm{Ti}$ contribution to $\mathrm{SiO}_{2}$ is insignificant (Figure 7 and Figure 8). The weak positive correlation of $\mathrm{Na}_{2} \mathrm{O}$ with $\mathrm{K}_{2} \mathrm{O}$ suggests the insignificant contribution of alkali feldspar to the sediment, and the positive correlation of $\mathrm{Na}_{2} \mathrm{O}$ with $\mathrm{Ca}$ suggests that $\mathrm{Ca}$ distribution in the sediment is associated with feldspar.

The classification of terrigenous sediments based upon a plot of $\log$ $\left(\mathrm{Na}_{2} \mathrm{O} / \mathrm{K}_{2} \mathrm{O}\right)$ vs $\log \left(\mathrm{SiO}_{2} / \mathrm{Al}_{2} \mathrm{O}_{3}\right)$ which showed that the sediment are mainly quartz arenite and sublitharenite with few subarkose and grakwacke [39] (Figure 9). Also, plot of $\log \left(\mathrm{Fe}_{2} \mathrm{O}_{3} / \mathrm{K}_{2} \mathrm{O}\right)$ vs $\log \left(\mathrm{SiO}_{2} / \mathrm{Al}_{2} \mathrm{O}_{3}\right)$, suggested that the sediments of the study areas are quartz arenite and Shale; with very few Fe shale and sublitharanite. The Fe shale is an indication of ferruginization and the quartz arenite suggest maturity and enrichment of quartz in the area [39] [40] (Figure 10).

\subsubsection{Trace Element Geochemistry}

Trace element geochemistry is very useful especially for the purpose of provenance studies and in deducing provenance setting of sedimentary succession 
O. A. Boboye et al.

Table 2. Major elemental ratios in the study areas.

\begin{tabular}{cccccccccc}
\hline Samples & $\mathrm{Al}_{2} \mathrm{O}_{3} / \mathrm{SiO}_{2}$ & $\mathrm{SiO}_{2} / \mathrm{Al}_{2} \mathrm{O}_{3}$ & $\mathrm{~K}_{2} \mathrm{O} / \mathrm{Al}_{2} \mathrm{O}_{3}$ & $\mathrm{~K}_{2} \mathrm{O} / \mathrm{Al}_{2} \mathrm{O}_{3}$ & $\mathrm{Al}_{2} \mathrm{O}_{3} / \mathrm{TiO}_{2}$ & $\mathrm{Na}_{2} \mathrm{O} / \mathrm{Al}_{2} \mathrm{O}_{3}$ & $\mathrm{Na}_{2} \mathrm{O} / \mathrm{TiO}_{2}$ & $\mathrm{Na}_{2} \mathrm{O} / \mathrm{K}_{2} \mathrm{O}$ & $\mathrm{TiO}_{2} / \mathrm{Al}_{2} \mathrm{O}_{3}$ \\
\hline Kanadi- $A$ & 0.13 & 7.4 & 0.05 & 0.05 & 16.07 & 0.0009 & 0.01 & 0.02 & 0.062 \\
Kanadi- $B$ & 0.23 & 4.32 & 0.009 & 0.01 & 19.17 & 0.0006 & 0.012 & 0.07 & 0.05 \\
Kanadi- $C$ & 0.25 & 4.06 & 0.04 & 0.04 & 19.73 & 0.0006 & 0.01 & 0.014 & 0.051 \\
Kanadi- $D$ & 0.25 & 5.1 & 0.57 & 0.57 & 16.67 & 0.0009 & 0.014 & 0.002 & 0.06 \\
Kanadi- $E$ & 0.21 & 4.85 & 0.54 & 0.54 & 16.67 & 0.0008 & 0.014 & 0.002 & 0.06 \\
Kanadi- $F$ & 0.24 & 8.02 & 0.17 & 0.17 & 23.35 & 0.001 & 0.023 & 0.006 & 0.043 \\
Albarka- $A$ & 0.24 & 4.15 & 0.07 & 0.07 & 19.79 & 0.0006 & 0.012 & 0.009 & 0.05 \\
Albarka- $B$ & 0.14 & 7.36 & 0.05 & 0.05 & 17.71 & 0.0009 & 0.016 & 0.017 & 0.06 \\
Albarka- $C$ & 0.13 & 7.82 & 0.05 & 0.05 & 19.47 & 0.0009 & 0.018 & 0.018 & 0.05 \\
Albarka- $D$ & 0.15 & 6.77 & 0.05 & 0.05 & 17.63 & 0.0008 & 0.015 & 0.015 & 0.057 \\
Albarka- $E$ & 0.21 & 4.72 & 0.53 & 0.51 & 19.29 & 0.0008 & 0.015 & 0.002 & 0.052 \\
Tuma- $A$ & 0.24 & 4.16 & 0.035 & 0.04 & 22.85 & 0.0006 & 0.013 & 0.016 & 0.044 \\
Tuma- $B$ & 0.14 & 7.18 & 0.05 & 0.05 & 20.39 & 0.0009 & 0.018 & 0.017 & 0.05 \\
Tuma- $C$ & 0.21 & 10.51 & 0.23 & 0.23 & 40.96 & 0.001 & 0.05 & 0.005 & 0.024 \\
Tuma- $D$ & 0.21 & 4.85 & 0.5 & 0.5 & 19.78 & 0.0008 & 0.015 & 0.0015 & 0.051 \\
Dange- $A$ & 0.1 & 10.47 & 0.05 & 0.05 & 14.58 & 0.0012 & 0.019 & 0.027 & 0.068 \\
Seme- $A$ & 0.06 & 16.07 & 0.41 & 0.4 & 33.08 & 0.0018 & 0.06 & 0.004 & 0.03 \\
\hline
\end{tabular}
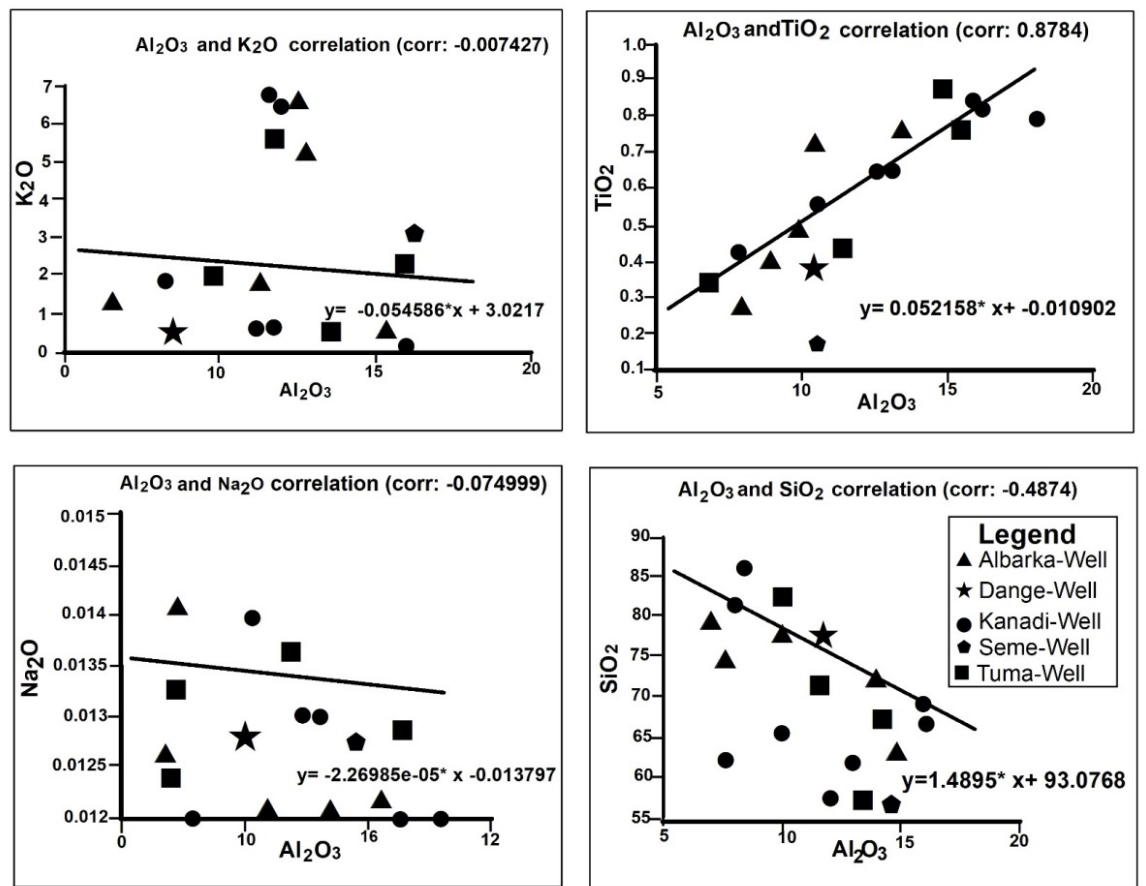

Figure 8. Bivariate correlation plots of major elements in the study wells.

[10] [41] [42] [43]. The trace element concentration of the study area are enriched in $\mathrm{Zr}$ and $\mathrm{Ba}$, they are moderately enriched in $\mathrm{Co}$ and $\mathrm{Rb}$ (Table 3). The classification scheme for representing trace element abundance and 


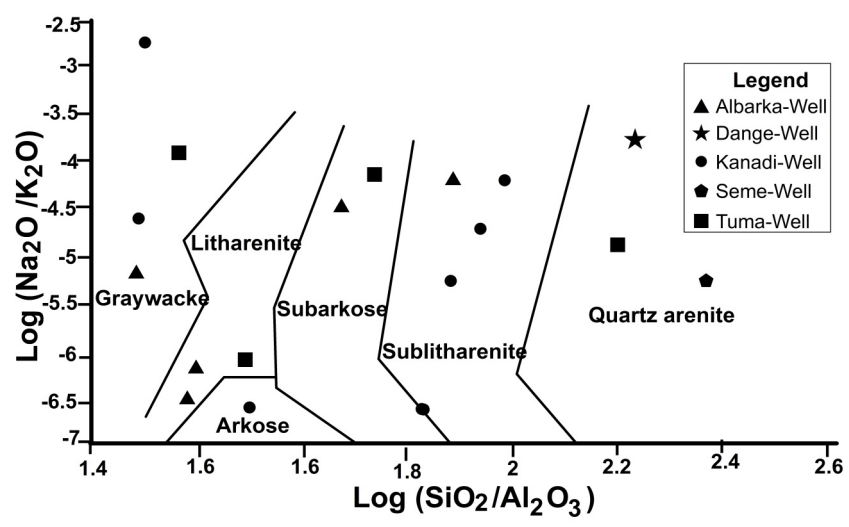

Figure 9. Chemical classification of sediments from the studied areas [45].

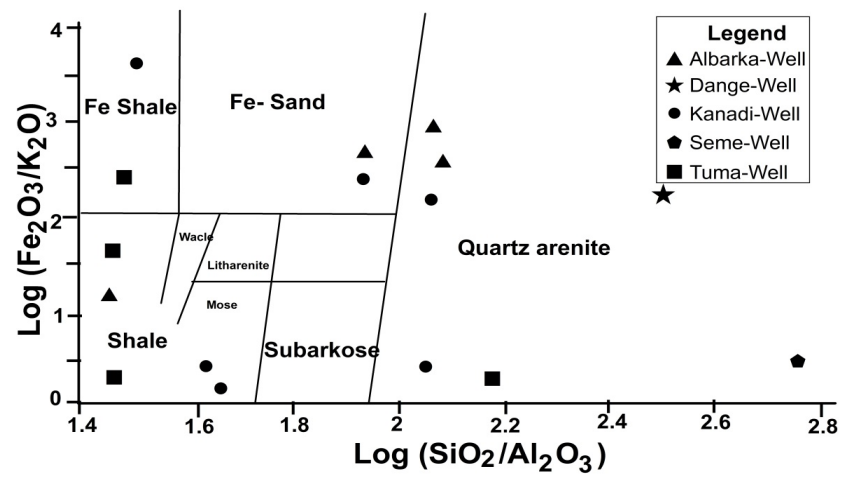

Figure 10. Chemical classification of sediments from the studied areas [40].

distribution relative to the Upper Continental Crust (UCC) includes; the large ion lithophile elements (LILE), $\mathrm{Sr}$ and the transition trace element (TTE) $\mathrm{Cr}, \mathrm{Ni}$, and Sc [44].

The large ion lithophile elements (LILE)

In the study area, the negative correlation of $\mathrm{Sr}$ and $\mathrm{Ba}$ with $\mathrm{Al}_{2} \mathrm{O}_{3}(\mathrm{r}=00.29$ and 0.60 ) suggest that their distribution is not mainly controlled by phyllosilicate [44] (Figure 11). The Sr content (18 ppm - $1760 \mathrm{ppm}$ ) in the study area is variable due to many influences on the $\mathrm{Sr}$ in warm temperature deposited environment. The significance positive correlation $(r=0.14)$ between $\mathrm{Ba}$ and $\mathrm{K}_{2} \mathrm{O}$ suggest that $\mathrm{Ba}$ is mainly associated with a feldspar component as it is an alkaline earth metal (Figure 11).

The Transition trace elements (TTE)

The transition trace elements are positively correlated with $\mathrm{Al}_{2} \mathrm{O}_{3}$. The correlation values of $\mathrm{Ni}(\mathrm{r}=0.31)$ and $\mathrm{Sc}(\mathrm{r}=0.32)$ indicate that they are mainly concentrated with phyllosilicates (Figure 11 and Figure 12).

\subsubsection{Rare Earth Elemental Geochemistry (REE)}

The REE are among the least traceable elements and are relatively immobile during low grade metamorphism, weathering and hydrothermal alteration. They 
Table 3. Trace elemental composition.

\begin{tabular}{ccccccccccccccccccc}
\hline Samples & $\mathrm{Rb}$ & $\mathrm{Sc}$ & $\mathrm{Sn}$ & $\mathrm{Ta}$ & $\mathrm{Th}$ & $\mathrm{U}$ & $\mathrm{W}$ & $\mathrm{Ba}$ & $\mathrm{V}$ & $\mathrm{Ni}$ & $\mathrm{Li}$ & $\mathrm{Sr}$ & $\mathrm{Co}$ & $\mathrm{Cs}$ & $\mathrm{Ga}$ & $\mathrm{Nb}$ & $\mathrm{Hf}$ & $\mathrm{Be}$ \\
\hline Kanadi- $A$ & 38.3 & 69 & 27 & 61 & 11.3 & 4 & 7 & 1810 & 56 & 30 & 18 & 124 & 14 & 3.1 & 17 & 67 & 10 & $<5$ \\
Kanadi-B & 56.4 & 50 & 21 & 3 & 11.2 & 2 & 4 & 172 & 129 & 27 & 73 & 162 & 20 & 4.6 & 20 & 19 & 139 & $<5$ \\
Kanadi-C & 41.6 & 66 & 20 & 23 & 15.4 & 4 & 6 & 2130 & 84 & 21 & 33 & 185 & 15 & 4.2 & 24 & 41 & 11 & $<5$ \\
Kanadi-D & 209 & 55 & 17 & 1.8 & 7.9 & 2 & 3 & 2960 & 102 & 34 & 21 & 913 & 32 & 4 & 15 & 8 & 101 & $<5$ \\
Kanadi-E & 188 & 69 & 15 & 1.6 & 5.3 & 1 & 3 & 3160 & 106 & 40 & 25 & 920 & 30 & 3.2 & 13 & 6 & 5 & $<5$ \\
Kanadi-F & 44.4 & 37 & 11 & 6.1 & 4.1 & 1 & 16 & 10000 & 39 & 10 & 22 & 1760 & 20 & 1.6 & 10 & 10 & 5 & $<5$ \\
Albarka- $A$ & 36.5 & 36 & 12 & 1.5 & 7.4 & 1 & 2 & 154 & 132 & 16 & 71 & 147 & 22 & 2.9 & 13 & 12 & 102 & $<5$ \\
Albarka- $B$ & 27.8 & 58 & 16 & 47 & 7.6 & 2 & 3 & 1620 & 54 & 29 & 17 & 105 & 13 & 2 & 11 & 41 & 161 & $<5$ \\
Albarka-C & 27.5 & 72 & 12 & 48 & 7.6 & 2 & 3 & 1390 & 47 & 25 & 15 & 99 & 11 & 2 & 12 & 42 & 7 & $<5$ \\
Albarka-D & 21 & 77 & 13 & 19 & 6.4 & 2 & 8 & 2240 & 63 & 19 & 20 & 138 & 10 & 1.7 & 13 & 27 & 7 & $<5$ \\
Albarka- $E$ & 158 & 53 & 12 & 1.4 & 5.7 & 1 & 2 & 2930 & 101 & 35 & 17 & 893 & 29 & 2.7 & 13 & 6 & 117 & $<5$ \\
Tuma- $A$ & 28.7 & 45 & 11 & 18 & 9.5 & 3 & 3 & 1880 & 70 & 16 & 25 & 152 & 14 & 2.6 & 17 & 28 & 187 & $<5$ \\
Tuma- $B$ & 36.7 & 37 & 8 & 35 & 6.5 & 2 & 4 & 1560 & 51 & 16 & 16 & 99 & 13 & 1.6 & 12 & 35 & 8 & $<5$ \\
Tuma-C & 31.3 & 35 & 7 & 4.1 & 2.2 & 1 & 9 & 10000 & 23 & 6 & 12 & 836 & 10 & 0.8 & 8 & 6 & 154 & $<5$ \\
Tuma-D & 75.7 & 21 & 5 & 0.7 & 2.3 & 0 & $>1$ & 2440 & 96 & 13 & 14 & 750 & 30 & 0.9 & 9 & 2 & 3 & $<5$ \\
Dange- $A$ & 15 & 18 & 6 & 1.6 & 2 & 3 & 26 & 1140 & 47 & 11 & 32 & 230 & 38 & 0.4 & 8 & 4 & 14 & $<5$ \\
Seme- $A$ & 12.5 & 26 & 7 & 1.4 & 1.8 & 1 & 4 & 10000 & 24 & 5 & 12 & 455 & 4.8 & 0.3 & 7 & 1 & 58 & $<5$ \\
\hline
\end{tabular}

are effective indicator of sediments source when compared with the upper continental crust, oceanic crust and mantle minerals. The pathway followed by elements during weathering and subsequent deposition as sediment is best understood by the behavior often revealed by the REE in authigenic and biogenic sedimentary phrase and seawater. The distribution of REE in seawater often reveals their fractionation in sediments while their concentration in rivers reveals their removal from seawater by authigenic and biogenic phrase resulting in decrease in their total concentration [46]. The concentration of REE in sediments result from completing influences of the provenance, weathering, diagenesis, sediment sorting and the aqueous geochemistry of the individual elements [47]. The REE Chondrite-Normalizing factor was used [48]. Other normalized plots and parameters used to characterize REE abundance includes:

1) $\Sigma$ REE,

2) HREE $(\mathrm{Gd} / \mathrm{Yb})_{\mathrm{N}}$,

3) LREE $(\mathrm{La} / \mathrm{Yb})_{\mathrm{N}}$,

4) ( $\Sigma$ LREE/ $\Sigma$ HREE) the ratio of the sum of light rare earth elements to the sum of heavy rare earth elements,

5) Total REE $(\mathrm{La} / \mathrm{Yb})_{\mathrm{N}}$,

6) $\mathrm{Eu} / \mathrm{Eu}^{*}$ anomaly which is the ratio of actual normalized $\mathrm{Eu}$ to interpolated normalized $\mathrm{Eu}$ for non-depletion or enrichment of the chondrite-normalised plots and is calculated by the following equation: $\mathrm{Eu} / \mathrm{Eu}^{*}=\sqrt{\mathrm{EuN}} /(\mathrm{SmN} \times \mathrm{GdN})$,

7) $\mathrm{Ce} / \mathrm{Ce}^{*}=5 \mathrm{Ce}_{\mathrm{N}} /\left[4 \mathrm{La}_{\mathrm{N}}+\mathrm{Sm}_{\mathrm{N}}\right]$.

Note: ${ }_{N}$ and ${ }^{*}$ indicate chondrite normalized elements. 

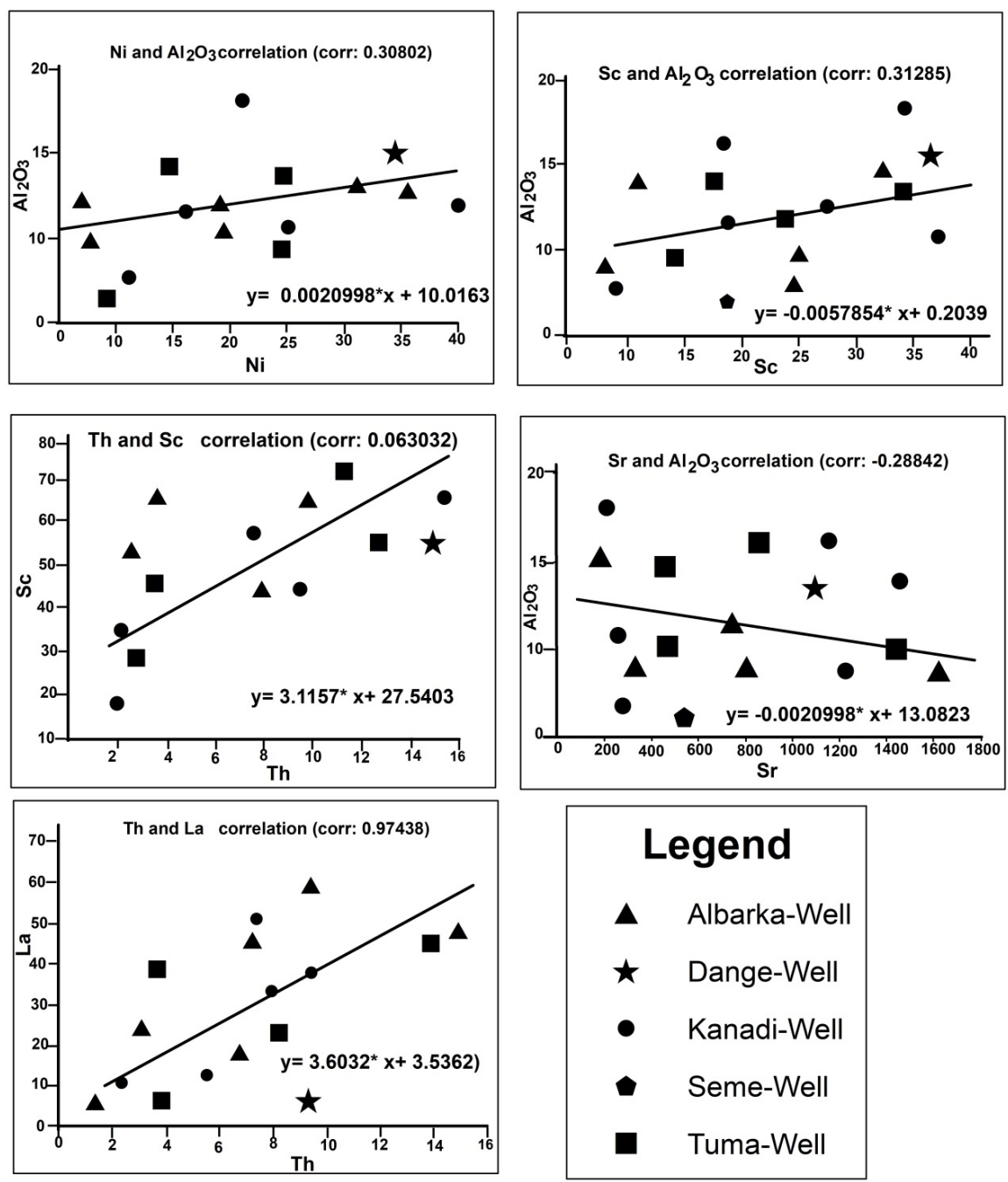

Figure 11. Bivariate correlation plots of trace elements in the study wells.

In the study areas, the concentrations of REE are highly variable with appreciable enrichment in the LREE (La-Nd) over the HREE (Er-Lu) as evident in the Chondrite normalized plot (Figure 13). Tm, Ho and $\mathrm{Yb}$ are the least enriched evidenced from their sharp concave shape. $\mathrm{Eu} / \mathrm{Eu}^{*}$ is the parameter used to evaluate the abundance of plagioclase in an igneous rock or its sedimentary derivative while higher LREE/HREE ratio and negative $\mathrm{Eu}$ anomalies denote felsic source rocks thus the negative $\mathrm{Eu}$ anomalies from this area indicated that the sediments are from felsic source rock [42].

$\mathrm{Ce} / \mathrm{Ce}^{*}$ was used to determine the environmental condition at the time of deposition since the value higher than 1 tentatively depict an oxidizing environment, however, the $\mathrm{Ce} / \mathrm{Ce}^{*}$ value of 1.006 , suggest that the sediments were deposited in a relatively oxidizing environment [49].

\subsection{Source Area Weathering}

The weathering history of ancient sedimentary rocks can be evaluated in part by examining relationships among the alkali and alkaline earth elements [30]. This 

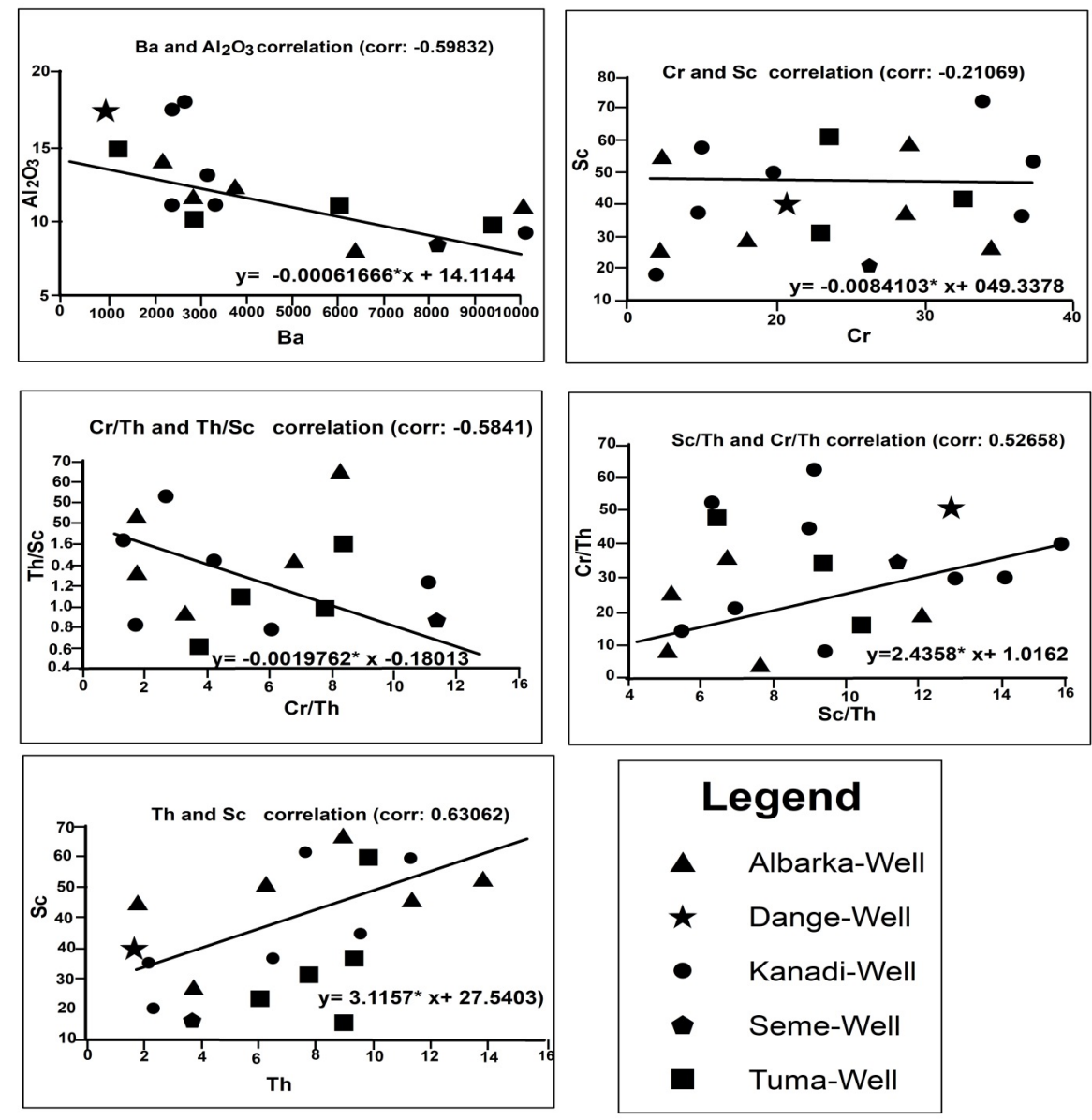

Figure 12. Bivariate correlation plots of trace elements for the study wells.

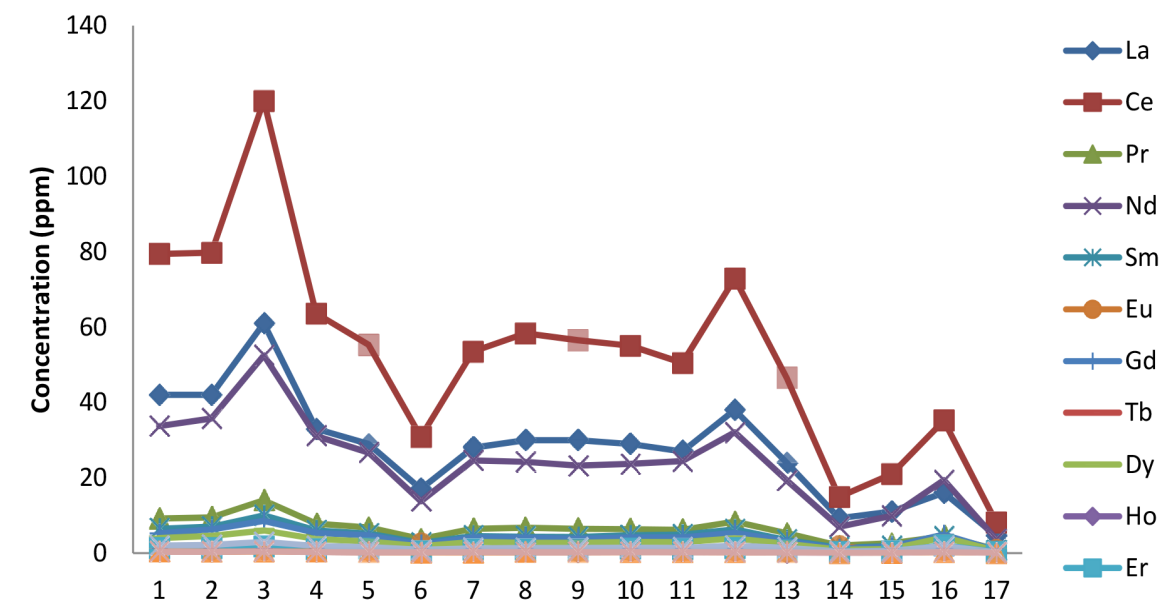

Figure 13. Chondrite normalized spider diagram for the concentration of rare earth elements in the study wells.

is because alteration of igneous rocks in sediments during weathering results in depletion of alkali and alkaline earth elements and preferential enrichment of $\mathrm{Al}_{2} \mathrm{O}_{3}$ in sediments. The indices used for quantitative estimation of the degree of chemical weathering in the study areas include; Chemical Index of Alteration 
(CIA), Plagioclase index of Alteration (PIA) and Chemical Index of Weathering (CIW) in obtaining CIA, PIA and CIA [30] [50] [51];

$$
\begin{gathered}
C I A=100\left[\mathrm{Al}_{2} \mathrm{O}_{3} /\left(\mathrm{Al}_{2} \mathrm{O}_{3}+\mathrm{CaO}+\mathrm{Na}_{2} \mathrm{O}+\mathrm{K}_{2} \mathrm{O}\right)\right] \\
P I A=100\left[\mathrm{Al}_{2} \mathrm{O}_{3}-\mathrm{K}_{2} \mathrm{O} / \mathrm{Al}_{2} \mathrm{O}_{3}+\mathrm{CaO}+\mathrm{Na}_{2} \mathrm{O}-\mathrm{K}_{2} \mathrm{O}\right] \\
C I W=100\left[\mathrm{Al}_{2} \mathrm{O}_{3} /\left(\mathrm{Al}_{2} \mathrm{O}_{3}+\mathrm{CaO}+\mathrm{NA}_{2} \mathrm{O}\right)\right]
\end{gathered}
$$

The CIA, PIA and CIW values range from 48.59\% - 92.45\%, 46.84\% - 96.23\% and $58.13 \%-98.55 \%$ with an average of $74.98 \%, 79.82 \%$ and $84.68 \%$ respectively (Table 4). These values are variable and may be as a result of multiple provenances for the sediment which have variable proportion of source area weathering and related process or may be due to low concentration of the alkaline and alkaline earth elements. Nevertheless, majority of the samples show CIA, PIA and CIW values greater than $70 \%$ (Table 5 and Table 6) indicating moderate to high (intensive) weathering either at the source or during transport before deposition. The relationship between $\mathrm{Th} / \mathrm{U}$ ratio and Th concentration can also be applied as an estimate of the degree of weathering in sedimentary rocks [41]. Both Th and $U$ are relatively immobile during weathering, although, $U$ may change its redox state during reworking under aerobic conditions and it is thus more readily removed from the system thereby increasing the $\mathrm{Th} / \mathrm{U}$ ratio above upper crust igneous values. In sedimentary rocks, Th/U values higher than 4.0 may indicate intense weathering in the source areas or sedimentary recycling. Th/U ratios in the study areas range from $0.75-5.22$ with an average of 3.60. This is an indication of intense weathering in the source areas or sediment recycling.

\subsection{Provenance Indices}

Several classifications have been proposed to discriminate sediments into various tectonic settings [5] [10] [11]. The provenance signatures employed for this study has distinguished the sources of the sediments into four provenance zones; mafic, intermediate or felsic, igneous and quartzose sedimentary. This discriminant function diagram makes use of the oxides of $\mathrm{Ti}, \mathrm{Al}, \mathrm{Fe}, \mathrm{Mg}, \mathrm{Ca}, \mathrm{Na}$ and $\mathrm{K}$ to effectively differentiate the sediments into four provenance zones [11]. They also noted that biogenic $\mathrm{CaO}$ and $\mathrm{SiO}_{2}$ in provenance determination could be eliminated by a plot in which the discriminant functions are based upon the ratios of individual $\mathrm{TiO}_{2}, \mathrm{Fe}_{2} \mathrm{O}_{3}, \mathrm{MgO}$ and $\mathrm{K}_{2} \mathrm{O}$ to $\mathrm{Al}_{2} \mathrm{O}_{3}$ which is more reliable and effective. The discriminant functions for the two plots used to discriminate the sediments within the study area are based on:

$$
\begin{aligned}
\text { Discriminant Function }(D F 1)= & 1.773 \mathrm{TiO}_{2}+0.607 \mathrm{Al}_{2} \mathrm{O}_{3}+0.76 \mathrm{Fe}_{2} \mathrm{O}_{3(\mathrm{~T})} \\
- & 1.5 \mathrm{MgO}+0.616 \mathrm{CaO}+0.509 \mathrm{Na}_{2} \mathrm{O} \\
& -1.224 \mathrm{~K}_{2} \mathrm{O}-9.09 \\
\text { Discriminant Function }(D F 2)= & 0.445 \mathrm{TiO}_{2}+0.07 \mathrm{Al}_{2} \mathrm{O}_{3}-0.25 \mathrm{Fe}_{2} \mathrm{O}_{3(\mathrm{~T})} \\
& -1.42 \mathrm{MgO}+0.438 \mathrm{CaO}+1.475 \mathrm{Na}_{2} \mathrm{O} \\
+ & 1.426 \mathrm{~K}_{2} \mathrm{O}-6.861
\end{aligned}
$$




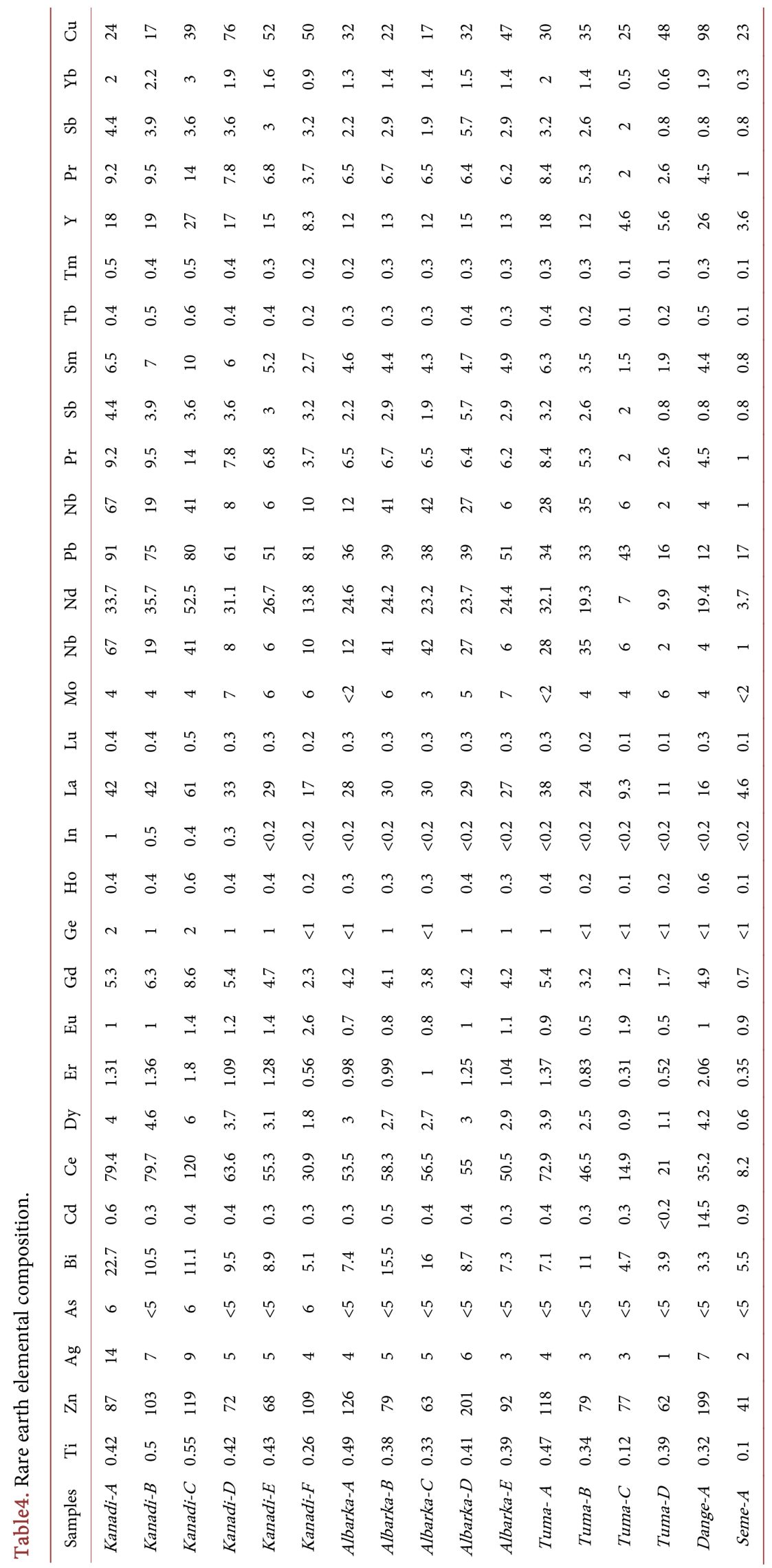


Table 5. Percentages of CIA, PIA and PIW values for the study wells.

\begin{tabular}{lcccc}
\hline Locations & Lithology & PIA (\%) & CIW (\%) & CIA (\%) \\
\hline Kanadi- $A$ & Mudstone & 95.16365 & 95.41045 & 90.77806 \\
Kanadi- $B$ & Brownish Shale & 82.34606 & 82.47759 & 81.86763 \\
Kanadi- $C$ & Light Sandstone & 94.32951 & 94.53999 & 91.15636 \\
Kanadi- $D$ & Dark shale & 46.84669 & 67.23381 & 48.59503 \\
Kanadi- $E$ & Dark Sandstone & 46.54729 & 65.52601 & 48.35667 \\
Kanadi- $F$ & Shaly Sandstone & 82.98989 & 85.50382 & 74.4943 \\
Albarka- $A$ & Mudstone & 80.7606 & 81.82761 & 77.52793 \\
Albarka- $B$ & Brownish Sandstone & 95.02809 & 95.28232 & 90.64726 \\
Albarka- $C$ & Brownish shale & 95.31717 & 95.54357 & 91.13746 \\
Albarka- $D$ & Brownish Sandstone & 94.12476 & 94.44079 & 89.6201 \\
Albarka- $E$ & Dark shale & 51.82794 & 69.38102 & 50.85157 \\
Tuma- $A$ & Light shale & 95.38938 & 95.54343 & 92.45432 \\
Tuma- $B$ & Brownish Sandstone & 96.23085 & 96.41633 & 91.89415 \\
Tuma- $C$ & Light shale & 88.00145 & 90.47309 & 75.01944 \\
Tuma- $D$ & Dark shale & 57.57458 & 73.25701 & 53.48605 \\
Dange- $A$ & Dark shale & 56.9304 & 58.13134 & 56.5544 \\
Seme- $A$ & Dark shale & 97.58474 & 98.55663 & 70.27743 \\
\hline & & & & \\
\hline & & & &
\end{tabular}

Table 6. Summary of source area weathering for the study wells.

\begin{tabular}{llcc}
\hline \multicolumn{2}{c}{ Indices } & $\begin{array}{c}\text { Standard } \\
(\%)\end{array}$ & $\begin{array}{c}\text { Study areas } \\
(\%)\end{array}$ \\
\hline \multirow{3}{*}{ CIA } & Range & $75-100$ & $48.59-92.45$ \\
& Mean & - & 74.98 \\
\multirow{2}{*}{ PIA } & Range & $75-100$ & $46.84-96.23$ \\
& Mean & - & 79.82 \\
\multirow{2}{*}{ CIW } & Range & $75-100$ & $58.13-98.55$ \\
& Mean & - & 84.68 \\
\hline
\end{tabular}

(Based on Osae et al:; Harnois, Nesbitt and Young) [30] [51] [52].

while that of the ratio plot is given as:

$$
\begin{aligned}
\text { Discriminant Function }(D F 1)= & 30.638 \mathrm{TiO}_{2} / \mathrm{Al}_{2} \mathrm{O}_{3}-12.541 \mathrm{Fe}_{2} \mathrm{O}_{3(\mathrm{~T})} / \mathrm{Al}_{2} \mathrm{O}_{3} \\
+ & 7.329 \mathrm{MgO} / \mathrm{Al}_{2} \mathrm{O}_{3}+12.031 \mathrm{Na}_{2} \mathrm{O} / \mathrm{Al}_{2} \mathrm{O}_{3} \quad .(3) \\
+ & 35.402 \mathrm{~K}_{2} \mathrm{O} / \mathrm{Al}_{2} \mathrm{O}_{3}-6.382 \\
\text { Discriminant Function }(D F 2)= & 56.500 \mathrm{TiO}_{2} / \mathrm{Al}_{2} \mathrm{O}_{3}-10.879 \mathrm{FeO}_{(\mathrm{T})} / \mathrm{Al}_{2} \mathrm{O}_{3} \\
& +30.875 \mathrm{MgO} / \mathrm{Al}_{2} \mathrm{O}_{3}-5.404 \mathrm{Na}_{2} \mathrm{O} / \mathrm{Al}_{2} \mathrm{O}_{3} \cdot(4) \\
& +11.112 \mathrm{~K}_{2} \mathrm{O} / \mathrm{Al}_{2} \mathrm{O}_{3}-3.89
\end{aligned}
$$

The plots using the raw oxides revealed that the sediments within the study area were probably sourced mainly from both felsic igneous provenance and In- 
termediate igneous provenance while the ratio plots also suggested felsic igneous provenance, intermediate igneous provenance and quartzose sedimentary provenance (Figure 14 and Figure 15). Recycled sources represent quartzose sediments of mature continental provenance and the derivation of the sediments could be from a highly weathered granite-gneiss terrain and/or from a pre-existing sedimentary terrain [11]. Also recycled sediments and sedimentary rocks allow expected enrichment of $\mathrm{Zr}$, reflecting its addition as evident from the trace element study [53].

\subsection{Depositional Environment}

The depositional environment for the studied area was classified based on the ternary plot of [54]. This involves the chemical classification on the basis of $\mathrm{Al}_{2} \mathrm{O}_{3}-\left(\mathrm{K}_{2} \mathrm{O}+\mathrm{Na}_{2} \mathrm{O}+\mathrm{CaO}\right)-\left(\mathrm{FeO}_{3}+\mathrm{MgO}\right)$ contents $(\mathrm{A}-\mathrm{K}-\mathrm{F})$, from the plot, there is a gradual transition of the sediments from continental to transition environment which depict a marine environment (Figure 16). This indicate that the sediment were transported from continental environment before being deposited in the marine environment, showing that the sediments underwent a low to moderate transportation level under oxidizing conditions.

\subsection{Provenance and Tectonic Setting}

Bhatia and Crook used La, Th and Sc concentration to discriminate sediments derived from oceanic island arc, continental island arc and from active and passive continental margin [10]. The La-Th-Sc ternary plots indicated mainly of active continental arc and passive margin region (Figure 17). The correlation of La and Th show significant positive correlation $(R=0.97)$ coefficient. The value of $\mathrm{La} / \mathrm{Th}$ ratio range from 2.6 to 8.2 (average $=4.34$ ) (Figure 12$)$, this positive correlation suggest a felsic source for the sediments but with the positive correlation shown by Sc/Cr, there is an indication of a mafic source. In establishing the felsic and mafic source for the sediments, the values of $\mathrm{Eu} / \mathrm{Eu}^{*},(\mathrm{La} / \mathrm{Lu})_{\mathrm{N}}, \mathrm{La} / \mathrm{Sc}$, $\mathrm{La} / \mathrm{Co}, \mathrm{Th} / \mathrm{Co}$ and $\mathrm{Cr} / \mathrm{Th}$ ratios in the study areas are similar to values of sediments derived from felsic source rock rather than mafic source rocks. The

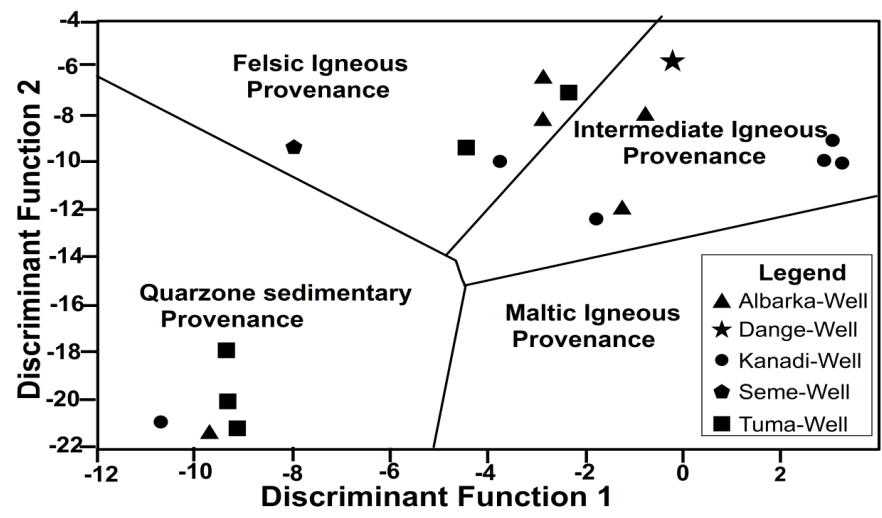

Figure 14. Discriminant function plot for the provenance signature of the wells using raw oxide [11]. 


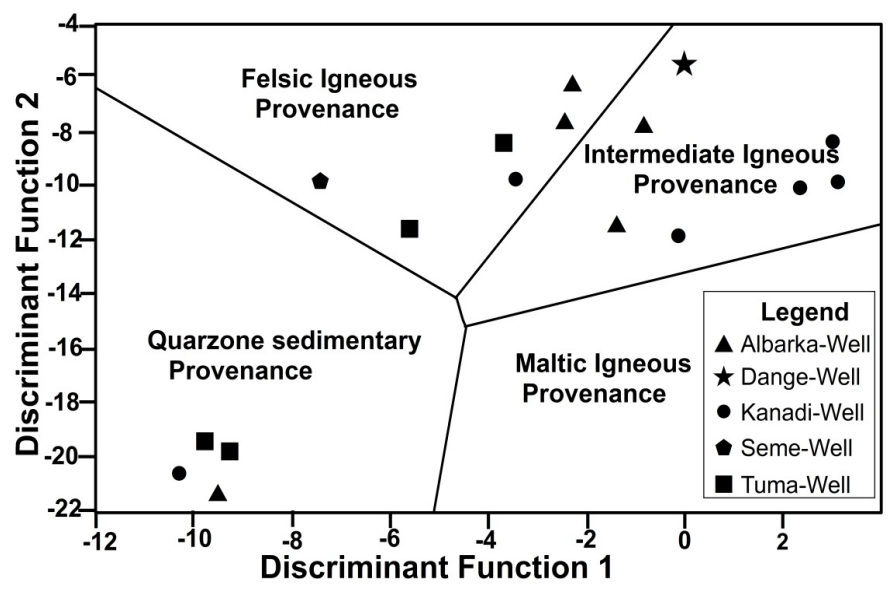

Figure 15. Discriminant function plot for the provenance signature of the wells using ratio plots [11].

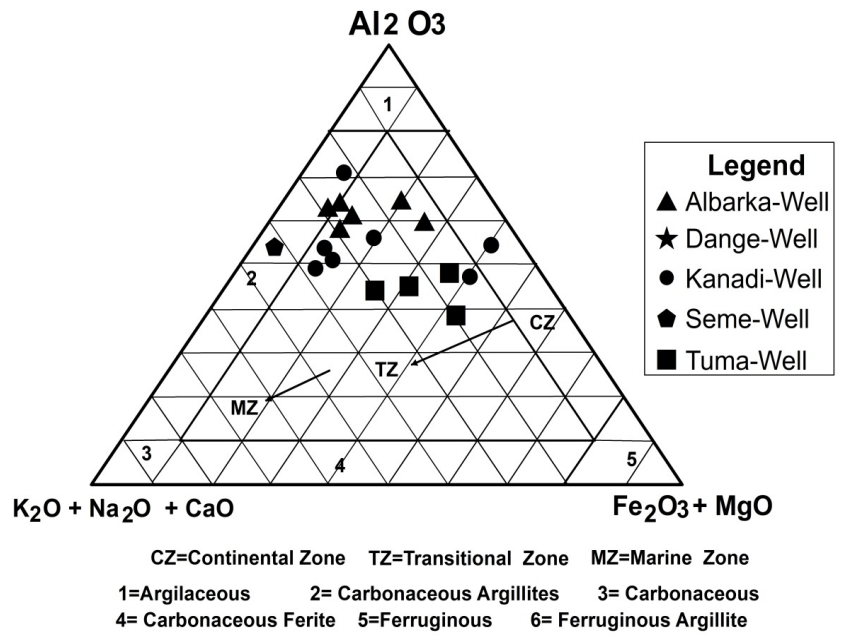

Figure 16. $\mathrm{Al}_{2} \mathrm{O}_{3}-\left(\mathrm{K}_{2} \mathrm{O}+\mathrm{CaO}+\mathrm{MgO}\right)-\left(\mathrm{Fe}_{2} \mathrm{O}_{3}+\mathrm{MgO}\right)(\mathrm{A}-\mathrm{K}-\mathrm{F})$ ternary plot for studied wells [54].

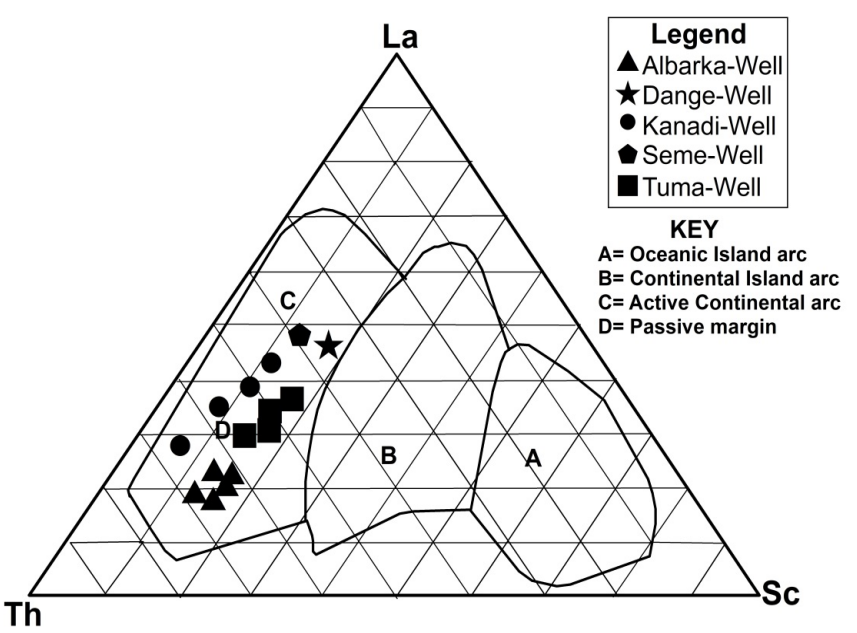

Figure 17. La-Th-Sc ratio plot [13]. 


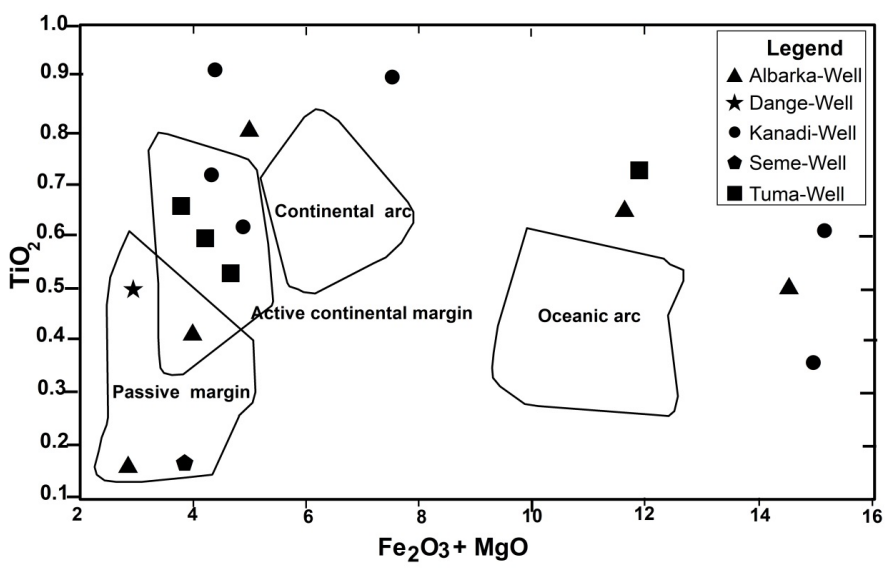

Figure 18. Discrimination diagram of the sediments [5].

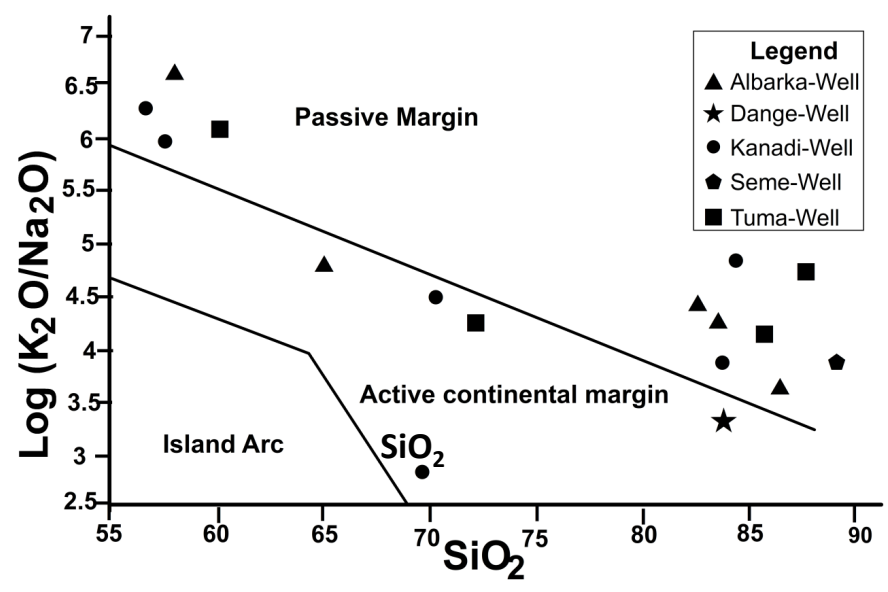

Figure 19. Tectonic discriminant diagram for the study areas [11].

discrimination diagram indicated that the study areas are within the passive margin region and active continental margin [5] (Figures 17-19). The discrimination diagram $\left(\log \left(\mathrm{K}_{2} \mathrm{O} / \mathrm{Na}_{2} \mathrm{O}\right)\right.$ vs $\left.\left(\mathrm{SiO}_{2}\right)\right)$ shows that more of the sediments are of the passive margin with a few active continental margin sources (Figure 19) [11].

\section{Conclusion}

The bulk of the geochemical study in these inland basins revealed that $\mathrm{SiO}_{2}$ is the dominant major element followed by $\mathrm{Al}_{2} \mathrm{O}_{3}$ and $\mathrm{Fe}_{2} \mathrm{O}_{3}$ which together made up about $90 \%$ of the composition of the sediment while the other major elements such as $\mathrm{K}_{2} \mathrm{O}, \mathrm{TiO}_{2}, \mathrm{CaO}, \mathrm{MgO}$ and $\mathrm{P}_{2} \mathrm{O}_{5}$ constitute the remaining percentage. The values for $\mathrm{SiO}_{2} / \mathrm{Al}_{2} \mathrm{O}_{3}$ ratio for the sediments are appreciably high indicating that the areas have been heavily weathered while the values of $\mathrm{TiO}_{2}$ and $\mathrm{Fe}_{2} \mathrm{O}_{3}$ indicated the presence of iron-titanium minerals. The $\mathrm{K}_{2} \mathrm{O} / \mathrm{Na}_{2} \mathrm{O}$ ratio values were attributed to the presence of orthoclase feldspar, which suggest that the areas are richer in $\mathrm{K}$-feldspar rather than in $\mathrm{Na}$-feldspar since the former is less mobile and more resistant to weathering. The high values of $\mathrm{Al}_{2} \mathrm{O}_{3}$ may also be 
attributed to a high degree of chemical weathering; the low values of the ratio $\mathrm{Na}_{2} \mathrm{O} / \mathrm{Al}_{2} \mathrm{O}_{3}, \mathrm{Na}_{2} \mathrm{O} / \mathrm{K}_{2} \mathrm{O}$ and $\mathrm{Na}_{2} \mathrm{O} / \mathrm{TiO}_{2}$ indicated that the sediments have undergone intense chemical weathering. The CIA, CIW and PIA parameters indicated an intense chemical weathering at the source areas. Herron's model classified the sediments into litharenites and quartz arenites. The discrimination function has characterized the sediments to be sourced from felsic igneous, quartzose sedimentary and intermediate igneous provenances. The trace elements studies via La-Th-Sc plot showed that the sediments are mainly from passive marginal coast. Conversely, the negative correlation of $\mathrm{Th} / \mathrm{Sc}$ vs $\mathrm{Cr} / \mathrm{Th}$ and the positive correlation of $\mathrm{Cr} / \mathrm{Th}$ vs $\mathrm{Sc} / \mathrm{Th}$ indicated that the sediments are sourced from felsic rock which also corroborated with the negative Eu anomaly. However, the quartz arenite and sublitharanite of the study areas have geochemical characteristic that suggests plutonic igneous rock as the main source rock in addition to low grade metamorphic and quartzose recycled sedimentary rock as the minor parent rock.

\section{References}

[1] Jones, H.A. and Hockey, R.D. (1964) The Geology of Part of Southwestern Nigeria. Geological Survey Nigeria Bulletin, 31, 1-101.

[2] Fayose, E.A. (1970) Stratigraphic Paleontology of Afiwo Well, Southwestern Nigeria. Journal of Mining Geology, 5, 1-99.

[3] Omatsola, M.E. and Adegoke, O.S. (1981) Tectonic Evolution and Cretaceous Stratigraphy of the Dahomey Basin. Journal of Mining Geology, 18, 130-137.

[4] Idowu, J.O. and Ekweozor, C.M. (1993) Petroleum Potential of Cretaceous Shales in the Upper Benue Trough, Nigeria. Journal of Petroleum Geology, 21, 105-118. https://doi.org/10.1111/j.1747-5457.1993.tb00337.x

[5] Bhatia, M.R. (1983) Plate Tectonics and Geochemical Composition of Sandstones. Journal of Geology, 27, 611-627. https://doi.org/10.1086/628815

[6] Avbovbo, A.A., Ayoola, E.O. and Oshahon, G.A. (1986) Depositional and Structural Styles in Chad Basin of Northeastern Nigeria. Bulletin of American Association of Petroleum Geology, 70, 1787-1798.

[7] Kingston, D.R., Dishroon, C.P. and Williams, P.A. (1983) Global Basin Classification System. Bulletin of American Association of Petroleum Geology, 67, 2175-2193.

[8] Carter, J.D., Barber, W., Tait, E.A. and Jones, G.P. (1963) The Geology of Parts of Adamawa, Bauchi and Borno Provinces in Northeastern Nigeria. Nigeria Geology Survey Bulletin, 30, 1-108.

[9] Boboye, O.A. (2012) Late Albian-Eocene Palynological Biostatigraphy of Three Wells in the Nigerian Sector of Chad (Bornu) Basin. Journal of Mining and Geology, 48, 127-158.

[10] Bhatia, M.R. and Crook, K.A. (1986) Trace Element Characteristics of Graywackes and Tectonic Setting Discrimination of Sedimentary Basins. Journal of Mineralogy and Petrology, 92, 181-193. https://doi.org/10.1007/BF00375292

[11] Roser, B.P. and Korsch, R.J. (1986) Determination of Tectonic Setting of Sandstone. Mudstone Suites Using $\mathrm{SiO}_{2}$ Content and $\mathrm{K}_{2} \mathrm{O} / \mathrm{Na}_{2} \mathrm{O}$ Ratio. Journal of Geology, 94, 635-650. https://doi.org/10.1086/629071 
[12] Roser, B.P. and Korsh, R.J. (1988) Provenance Signatures of Sandstone-Mudstone Suites as Determined Using Discriminant Function Analysis of Major Element Data. Journal of Chemical Geology, 67, 119-139. https://doi.org/10.1016/0009-2541(88)90010-1

[13] Allen, J.R.L. (1970) Physical Processes of Sedimentation. Allen and Unwin, London, 248.

[14] Berner, R.A. (1971) Principles of Chemical Sedimentology. McGraw Hill, Inc., New York, 225-227

[15] Burke, K. (1976) The Chad Basin: An Active Intra-Continental Basin. Journal of Tectonophysics, 36, 197-206. https://doi.org/10.1016/B978-0-444-41549-3.50018-9

[16] Fairhead, J.D. and Blinks, R.M. (1991) Differential Opening of the Central and South Atlantic Oceans and the Opening of the Central African Rift System. Journal of Tectonophysics, 187, 191-203. https://doi.org/10.1016/0040-1951(91)90419-S

[17] Genik, G.J. (1993) Regional Framework, Structural and Petroleum Aspects of Rift Basins in Niger, Chad and the Central African Republic. Journal of Tectonophysics, 213, 169-185.

[18] Boboye, O.A. and Akaegbobi, I.M. (2010) Sedimentological and Palyno-Environmental Appraisal of the Late Quaternary Sediments Northeastern, Bornu Basin. Quaternary International Journal, 262, 14-19. https://doi.org/10.1016/j.quaint.2010.08.004

[19] Boboye, O.A. (2013) Palynostratigraphic and Paleoecological Studies of Cretaceous Strata in the Bornu-Basin, Northeastern Nigeria. Materials and Geoenvironment Journal, 60, 17-29.

[20] Boboye, O.A. and Abimbola, A.F. (2012) Palyno-Environmental Study of Kemar-1 Well, Bornu Basin, NE Nigeria. Journal of Science Research, 11, 72-82.

[21] Barber, W. and Jones, D.C. (1965) The Geology and Hydrogeology of the Maiduguri Area, Borno Province. Geological Survey Nigeria Bulletin, 27, 1-117.

[22] Petters, S.W. (1979) Middle Cretaceous Paleoenvironments and Biostratigraphy of the Benue Trough, Nigeria. Bulletin of American Association of Petroleum Geology, 89, 151-154. https://doi.org/10.1130/0016-7606(1978)89<151:MPABOT >2.0.CO;2

[23] Lawal, O. and Moullade, M. (1986) Palynological Biostratigraphy of Creatceous Sediments in the Upper Benue Basin, N.E. Nigeria. Revised Micropaleontology, 29, 61-83.

[24] Boboye, O.A. and Uzegwu, U.A. (2014) Evaluation of the Biomolecular Signatures and Hydrocarbon Potential of Upper Cretaceous Shale, Northeastern Nigeria. Journal of African Earth Sciences, 99, 490-516. https://doi.org/10.1016/j.jafrearsci.2014.04.014

[25] Falconer, J.D. (1911) Geology and Geography of Northern Nigeria. Macmillan, London, 135.

[26] Raeburn, C. and Tattarm, C.M. (1980) A Preliminary Note on the Sedimentary Rocks of Sokoto Province. Bulletin of Nigeria Geological Survey, 13, 57-60.

[27] Kogbe, C.A. (1981) Cretaceous and Tertiary of the Iullemmeden Basin of Nigeria (West Africa). Cretaceous Resources, 2, 129-186.

https://doi.org/10.1016/0195-6671(81)90007-0

[28] Antolini, P. (1968) Eocene Phosphate in the Dahomey Basin. Journal of Mining Geology, 17, 99-106.

[29] Boboye, O.A. and Omotosho, O.J. (2017) Petrological and Geochemical Evaluation of the Paleocene-Eocene Lithofacies in Dahomey Embayment, Southwestern Nige- 
ria. Open Journal of Geology, 7, 690-719. https://doi.org/10.4236/ojg.2017.75047

[30] Nesbitt, H.W. and Young, G.M. (1982) Early Proterozoic Climates and Plate Motions Inferred from Major Element Chemistry of Lutites. Nature, 299, 715-717. https://doi.org/10.1038/299715a0

[31] Fedo, C.M., Nesbitt, H.W. and Young, G.M. (1995) Unraveling the Effects of Potassium Metasomatism in Sedimentary Rocks and Palaesols, with Implications for $\mathrm{Pa}$ leoweathering Conditions and Provenance. Journal of Geology, 23, 921-924. https://doi.org/10.1130/0091-7613(1995)023<0921:UTEOPM>2.3.CO;2

[32] Von Eynatten, H., Barcelo, V.C. and Pawlowsky, G.V. (2003) Composition and Distribution of Sandstones: A Stochastic Evaluation of Different Analytical Methods. Journal of Sedimentary Research, 73, 45-47. https://doi.org/10.1306/070102730047

[33] Nesbitt, H.W., Young, G.M., Mclannan, S.M. and Keays, R.R. (1996) Effects of Chemical Weathering and Sorting on the Petrogenesis of Siciclastic Sediments with Implications for Provenance Studies. Journal of Geology, 104, 525-542. https://doi.org/10.1086/629850

[34] Calvert, S.E. (1976) Geochemistry of Recent Oxic and Anoxic Marine Sediments: Implications for the Geological Record. Journal of Marine Geology, 113, 67-88. https://doi.org/10.1016/0025-3227(93)90150-T

[35] Chilinger, G.V. (1979) Relationship between Ca/Mg Ratio and Geological Age. Bulletin of American Association of Petroleum Geology, 40, 2225-2226.

[36] Bauluz, B., Mayayo, M.J., Fernandez-Nieto, C. and Gonzalez Lopez, J.M. (2000) Geochemistry of Precambrian and Paleozoic Siliciclastic Rocks from the Iberian Range (NE Spain) Implications for Source-Area Weathering, Sorting, Provenance, and Tectonic Setting. Chemical Geology, 168, 135-150. https://doi.org/10.1016/S0009-2541(00)00192-3

[37] Dabard, M.P. (1990) Lower Broverian Formations (Upper Proterozoic) of the Armorican Maesit (France) Geodynamic Evolution of Source Areas Revealed by Sandstone Petrography and Geochemistry. Journal of Sedimentary Geology, 69, 45-58. https://doi.org/10.1016/0037-0738(90)90100-8

[38] McLennan, S.M., Taylor, S.R. and Eriksson, K.A. (1983) Geochemistry of Archean Shales from the Pilbara Supergroup, Western Australia. Geochimica et Cosmochimica Acta, 47, 1211-1222. https://doi.org/10.1016/0016-7037(83)90063-7

[39] Pettijohn, F.J. (1975) Sedimentary Rocks. 3rd Edition, Harper \& Row, New York, 628.

[40] Herron, M.M. (1988) Geochemical Classification of Terrigenous Sands and Shales from Core to Log Data. Journal of Sedimentary Petrology, 58, 820-829.

[41] McLennan, S.M., Hemming, S., McDaniel, D.K. and Hanson, G.N. (1993) Geochemical Approaches to Sedimentation, Provenance, and Tectonics. Special Papers, Geological Society of America, 21. https://doi.org/10.1130/SPE284-p21

[42] Mclennan, S.M. (1989) Rare Earth Elements in Sedimentary Rocks: Influence of Provenance and Sedimentary Processes. Mineralogical Society of America Reviews in Mineralogy, 21, 169-200.

[43] McLennan, S.M. (2001) Relationships between the Trace Element Composition of Sedimentary Rocks and Upper Continental Crust. Geochemistry, Geophysics, Geosystems, 2, 154-155. https://doi.org/10.1029/2000GC000109

[44] López, J.M.G., Bauluz, B., Fernández-Nieto, C. and Oliete, A.Y. (2005) Factors Controlling the Trace-Element Distribution in Fine-Grained Rocks: The Albian 
Kaolinite-Rich Deposits of the Oliete Basin (NE Spain). Journal of Chemical Geology, 214, 1-19. https://doi.org/10.1016/j.chemgeo.2004.08.024

[45] Pettijohn, F.J., Potter, P.E. and Siever, R. (1972) Sand and Sandstone. Springer, New York, 618.

[46] Piper, D.Z. (1974) Rare Earth Elements in the Sedimentary Cycle: A Summary. Journal of Chemical Geology, 14, 285-304. https://doi.org/10.1016/0009-2541(74)90066-7

[47] Nesbitt, H.W. and Markovics, G. (1980) Chemical Processes Affecting Alkalis and Alkaline Earths during Continental Weathering. Geochimica et Cosmochimica Acta, 44, 1659-1666. https://doi.org/10.1016/0016-7037(80)90218-5

[48] Wakita, H., Rey, P. and Schmitt, R.A. (1971) Abundances of the 14 Rare-Earth Elements and 12 Other Trace Elements in Apollo 12 Samples: Five Igneous and One Breccia Rocks and Four Soils. Proceedings of the Lunar Science Conference, 2, 1319.

[49] McDaniel, D.K., Hemming, S.R., McLennan, S.M. and Hanson, G.N. (1994) Resetting of Neodymium Isotopes and Redistribution of REEs during Sedimentary Processes: The Early Proterozoic Chelmsford Formation, Sudbury Basin, Ontario, Canada. Geochimica et Cosmochimica Acta, 58, 931-941.

https://doi.org/10.1016/0016-7037(94)90516-9

[50] Feng, R. and Kerrich, R. (1990) Geochemistry of Fine-Grained Clastic Sediments in the Archean Abitibi Greenstone Belt, Canada: Implications for Provenance and Tectonic Setting. Geochimica et Cosmochimica Acta, 54, 1061-1081

[51] Harnois, L. (1988) The New Index, a New Chemical Index of Weathering. Journal of Sedimentary Geology, 55, 319-322. https://doi.org/10.1016/0037-0738(88)90137-6

[52] Osae, S., Asiedu, D.K., Banoeng-Yakubo, B., Koeberl, C. and Dampare, S.B. (2006) Provenance and Tectonic Setting of Late Proterozoic Buem Sandstones of Southeastern Ghana: Evidence from Geochemistry and Detrital Modes. Journal of African Earth Sciences, 44, 85-96. https://doi.org/10.1016/j.jafrearsci.2005.11.009

[53] Zimmermann, U. and Bahlburg, H. (2003) Provenance Analysis and Tectonic Setting of the Ordovician Clastic Deposits in the Southern Puna Basin, NW Argentina. Sedimentology, 50, 1079-1104. https://doi.org/10.1046/j.1365-3091.2003.00595.x

[54] Englung, J.O. and Jorgensen, P. (1973) A Chemical Classification System for Argillaceous Sediments and Factors Affecting Their Composition. Geologiska Föreningen i Stockholm Förhandlingar, 95, 87-97. https://doi.org/10.1080/11035897309455428 